\title{
Trifolium subterraneum cover cropping enhances soil fertility and weed seedbank dynamics in a Mediterranean apricot orchard
}

\author{
Aurelio Scavo ${ }^{1}$ (1) - Alessia Restuccia ${ }^{1}$. Cristina Abbate ${ }^{1} \cdot$ Sara Lombardo $^{1} \cdot$ Stefania Fontanazza ${ }^{1}$. \\ Gaetano Pandino $^{1}$. Umberto Anastasi ${ }^{1}{ }^{\mathbb{D}}$. Giovanni Mauromicale ${ }^{1}$
}

Accepted: 30 August 2021 / Published online: 21 October 2021

(c) The Author(s) 2021, corrected publication 2022

\begin{abstract}
The soils of Mediterranean semiarid environments are commonly characterized by low levels of organic matter and mineral elements, as well as severe weed infestations, which, taken together, cause an intensive use of auxiliary inputs (tillage, fertilizers, herbicides). Although cover crops are recognized to sustainably improve soil health, the impact of Trifolium subterraneum L. cover cropping needs specific attention. This research investigates for the first time the effects over 4 years of T. subterraneum and spontaneous flora cover crops, after either incorporating their dead mulches into the soil or leaving them on the soil surface, on soil organic matter (SOM), macroelements, mineral nitrogen, microelements, and weed seedbank dynamics as indicators of soil quality in an apricot orchard. Compared to a conventional management control, the T. subterraneum cover crop with the burying of dead mulch into the soil increased the amount of SOM $(+15 \%)$, ammoniacal $(+194 \%)$ and nitric $(+308 \%)$ nitrogen, assimilable $\mathrm{P}_{2} \mathrm{O}_{5}(+5 \%)$, exchangeable $\mathrm{K}_{2} \mathrm{O}(+14 \%)$, exchangeable $\mathrm{Na}(+32 \%)$, exchangeable $\mathrm{K}$ $(+16 \%), \mathrm{Fe}(+15 \%), \mathrm{Mn}(+28 \%), \mathrm{Zn}(+36 \%)$, and $\mathrm{Cu}(+24 \%)$, while it decreased the weed seedbank size $(-54 \%)$ and enhanced weed biodiversity. These findings suggest that $T$. subterraneum cover cropping may be an environment-friendly tool to enhance soil quality and limit auxiliary input supply in Mediterranean orchards.
\end{abstract}

Keywords Cover cropping $\cdot$ Subterranean clover $\cdot$ Soil health $\cdot$ Soil organic matter $\cdot$ Soil macroelements $\cdot$ Soil microelements · Weed soil seedbank

Umberto Anastasi

umberto.anastasi@unict.it

Aurelio Scavo

aurelio.scavo@unict.it

Alessia Restuccia

a.restuccia@unict.it

Cristina Abbate

cristina.abbate@unict.it

Sara Lombardo

saralomb@unict.it

Stefania Fontanazza

stefania.fontanazza@yahoo.it

Gaetano Pandino

g.pandino@unict.it

Giovanni Mauromicale

g.mauromicale@unict.it

1 Department of Agriculture, Food and Environment (Di3A), University of Catania, Via Valdisavoia, 5, 95123 Catania, Italy

\section{Introduction}

The weaknesses of agricultural activity (i.e., release of agrochemicals, loss of water resources, generation of ammonia from grazing (GAG) emission, soil degradation, and loss of biodiversity) are attributed to the irrational or inefficient use of auxiliary inputs and to the excessive biological homogeneity typical of intensive farming systems. Therefore, in agreement with the United Nations (UN) Sustainable Development Goals (SDGs) and with the strategies of the European Commission (EC) Green Deal, the transition of agricultural systems towards sustainability requires an agroecological and multifunctional approach in the management of agroecosystems (EC 2019; UN 2015). It is widely recognized that polyculture supports the stability and lesser dependence on external inputs of agroecosystems by using environmental resources (solar radiation, rainfall, $\mathrm{N}_{2}, \mathrm{CO}_{2}$, etc.) more effectively than monoculture (Finney and Kaye 2017). A number of researchers have demonstrated that the inclusion of cover crops in no-till farming systems ensures 
various ecosystem services (soil erosion control, carbon sequestration, reduction of nutrient leaching, degradation of agrochemicals, increase of biodiversity, pollinator attraction, etc.) (Blanco-Canqui et al. 2015; Daryanto et al. 2019; Kaye and Quemada 2017; Mauromicale et al. 2010; Sharma et al. 2018a, b; Wulanningtyas et al. 2021).

Areas under semiarid Mediterranean-type climates are commonly characterized by irregular rainfall regimes with intense autumnal events and drought in late spring and summer. In these climatic conditions, soils are often clayey, poor in organic matter, and subjected to erosion, which contribute to lowering the macro- and microelements' content (Lombardo et al. 2014; Madejón et al. 2007). The loss of soil minerals, particularly relevant for macronutrients such as nitrogen $(\mathrm{N})$ and phosphorous $(\mathrm{P})$, combined with the severe weed infestations, represents two critical aspects of Mediterranean agroecosystems, where an intensive and indiscriminate use of auxiliary inputs (tillage, fertilizers, and herbicides) is consequently adopted. In this framework, subterranean clover (Trifolium subterraneum L.), a self-pollinated annual legume with remarkable geocarpism, native to the Mediterranean Basin and widely diffused throughout the world in regions with Mediterranean-type climates (Australia, New Zealand, The Americas and South Africa), is considered an eligible cover crop, owing to its self-reseed and $\mathrm{N}$-fixation ability, rapid growth, and weed suppressive ability (Enache and Ilnicki 1990; Restuccia et al. 2020; Scavo et al. 2020). Subterranean clover has also proved to adapt well under organic farming and high tree density orchards thanks to its sciaphilic habitus (Mauro et al. 2011; Mauromicale et al. 2010). However, the magnitude of cover crop effects on soil quality closely depends on soil properties, management practices, climatic conditions, etc., thus making it important to locally evaluate these potential impacts over a medium-long-term period (Sharma et al. 2018a, b). Cover cropping effects on soil properties under Mediterranean semiarid conditions have already been investigated (Moreno et al. 2009; Ramos et al. 2020), but the influence of T. subterraneum cover cropping in Mediterranean apricot (Prunus armeniaca L.) orchards requires specific attention. In recent researches conducted in Sicily (southern Italy), important improvements have been observed in the weed control and nutritional status of soil in an apricot orchard managed with subterranean clover compared to spontaneous flora cover cropping and conventional soil management (disc ploughing and shallow chopping for weed control) (Restuccia et al. 2020; Scavo et al. 2020). Overall, the incorporation of T. subterraneum dead mulches into the soil significantly decreased the weed seedbank size and the weed aboveground biomass compared to other studied managements, while it increased the amount of ammonia-oxidizing (Nitrosomonas europaea) and $\mathrm{N}$-fixing (Azotobacter vinelandii) bacteria involved in the soil $\mathrm{N}$-cycle, which resulted in a significant enhancement of ammoniacal and nitric $\mathrm{N}$-availability in the soil.

Given that soil quality is a function of a complex network of interrelationships among physical, chemical, and biological properties, in which the organic matter (SOM) content plays a key role (Jiménez et al. 2002), and keeping in mind the benefits deriving from cover crops on soil health, especially under an integrated management strategy (Scavo and Mauromicale 2020), in this research, we have hypothesized that the optimization of $T$. subterraneum cover cropping management can allow lowering the environmental impact and enhancing the productivity of Mediterranean orchard agroecosystems through an equilibrium between the main soil quality indicators and weed pressure. Hence, the goals were to compare subterranean clover and spontaneous flora cover crops, burying or leaving their dead mulches on the soil surface, to a conventional management on a Mediterranean apricot orchard by monitoring the changes of SOM, macroand microelements, and weed seedbank over a 4 -year period (Fig. 1).

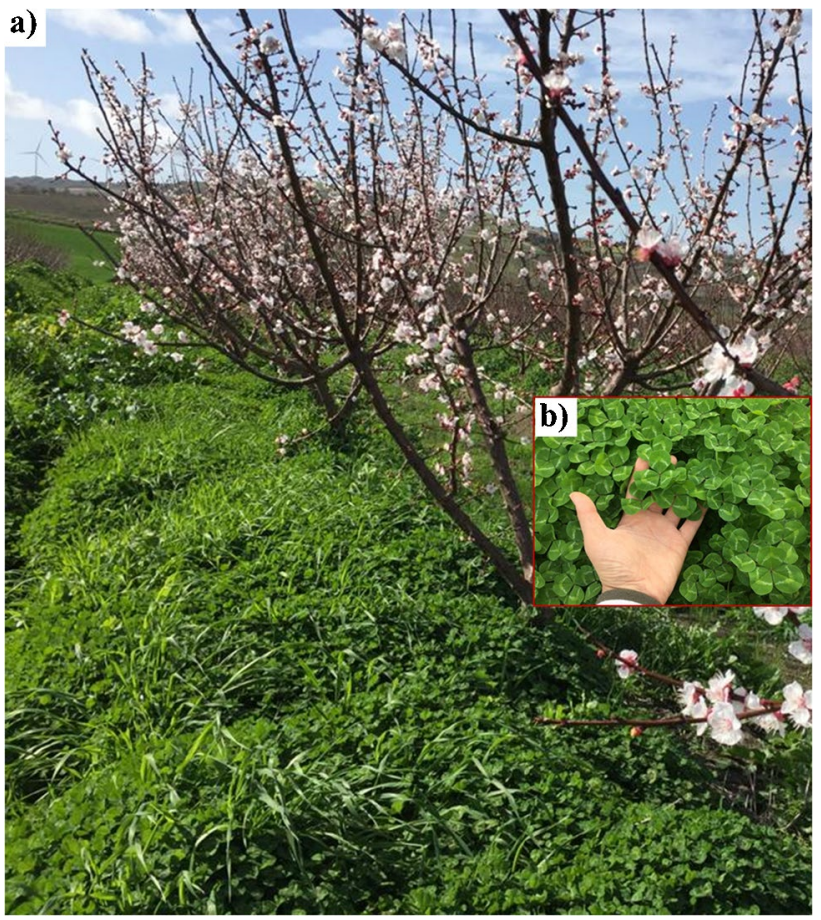

Fig. 1 a View of Trifolium subterraneum L. cover cropping in central Sicily (Italy). Detail of subterranean clover (b). Photographs by S. Fontanazza. 


\section{Materials and methods}

\subsection{Site and weather description}

The experiment was carried out over four growing seasons (I, II, III, and IV) from 2015/2016 to 2018/2019 in central Sicily $\left[37^{\circ} 13^{\prime}\right.$ N., $14^{\circ} 05^{\prime}$ E., $290 \mathrm{~m}$ a.s.l.], southern Italy. The area has a semiarid Mediterranean climate with mild winters, mean annual rainfall of $\sim 500 \mathrm{~mm}$, mostly concentrated in the fall-winter period, and summer droughts. According to the USDA soil taxonomy (Soil Survey Staff 1999), the soil is classified as Regosoil, and, at the beginning of the experiment, in the $0-40-\mathrm{cm}$ layer, it showed a clayey texture ( $25.7 \%$ sand, $30.6 \%$ silt, $43.7 \%$ clay), a $25 \%$ of gravel, and had the following mean characteristics: $1.9 \%$ organic matter; $6.1 \%$ total $\mathrm{CaCO}_{3} ; 5.6 \%$ active limestone; $\mathrm{pH}$ 8.0; electrical conductivity $1.3 \mathrm{dS}$ $\mathrm{m}^{-1}$; total $\mathrm{N} 1.1 \%$; available $\mathrm{P}_{2} \mathrm{O}_{5} 13 \mathrm{mg} \mathrm{kg}^{-1}$; exchangeable $\mathrm{K}_{2} \mathrm{O} 422 \mathrm{mg} \mathrm{kg}^{-1}$; cation exchange capacity (CEC) 49.6 meq $100 \mathrm{~g}^{-1}$; exchangeable bases $(\mathrm{Ca}, \mathrm{Mg}, \mathrm{Na}$, and K) 42.2, 5.4, 1.1, and $0.9 \mathrm{mg} 100 \mathrm{~g}^{-1}$, respectively; Fe $12.47 \mathrm{mg} \mathrm{kg}^{-1}$; Mn $3.75 \mathrm{mg} \mathrm{kg}^{-1}$; Cu $2.36 \mathrm{mg} \mathrm{kg}^{-1}$; and $\mathrm{Zn} 1.34 \mathrm{mg} \mathrm{kg}^{-1}$. The typical crops of the zone are cereals, legumes, olive, grape vineyard, carob, apricot, and peach orchards. In the last 3 years before the apricot orchard planting, the experimental field has been cultivated with wheat, chickpea, and a fallow year.

Climatic data including maxima and minima monthly temperatures and mean monthly rainfall were recorded from November 2015 to July 2019 by a meteorological station (Mod. Multirecorder 2.40; ETG, Firenze, Italy) located $\sim 15 \mathrm{~m}$ from the experimental area (Fig. 2). About $23 \%$ of the total 4-year rainfall fell in January 2016
(119 mm), February 2018 (109 mm), and October 2018 $(189 \mathrm{~mm})$. Air temperatures were always optimal for the establishment and growth of T. subterraneum. Indeed, minima temperatures fell below $3{ }^{\circ} \mathrm{C}$ only in January of season IV, while the mean maxima were $26{ }^{\circ} \mathrm{C}$ at emergence stage (October) and $21.5{ }^{\circ} \mathrm{C}$ at flowering stage (April) of subterranean clover.

\subsection{Experimental design and cover crop management}

A completely randomized block design was adopted, involving 5 treatments and 4 replicates. Cover cropping treatments included T. subterraneum with the leaving of dead mulch on the soil surface (TCC-S), T. subterraneum with the burying of dead mulch into the soil (TCC-B), spontaneous flora with the leaving of dead mulch on the soil surface (SCC-S), and spontaneous flora with the burying of dead mulch into the soil (SCC-B). The control was a conventional management (CM) ordinarily adopted for apricot orchards in the area where the experiment took place, which consists of $-15 \mathrm{~cm}$ winter disc ploughing (late September) and three shallow choppings (on November, February, and May, respectively) for weed control. The experiment was carried out in a large area of about 1 ha within a Mediterranean orchard. In particular, the area of each plot was $10 \times 8.7 \mathrm{~m}\left(87 \mathrm{~m}^{2}\right)$, for a net plot size of $348 \mathrm{~m}^{2}$, which intercepted 6 trees per treatment, and $1740 \mathrm{~m}^{2}$ in total (20 plots). Furthermore, in order to avoid interference during the soil sampling, a buffer area of $2 \mathrm{~m}$ in width was considered around each experimental plot (Fig. 3).

Apricot (cv. Wonder, together with 'Pinkcot ${ }^{\circledR}$ ' and 'Big Red ${ }^{\circledR}$ ' as pollinators) planting was conducted in January 2012 in a $3.5 \times 4.5 \mathrm{~m}$ layout. At the start of season I and
Fig. 2 Maxima and minima monthly temperatures and monthly total rainfall during the growing seasons.

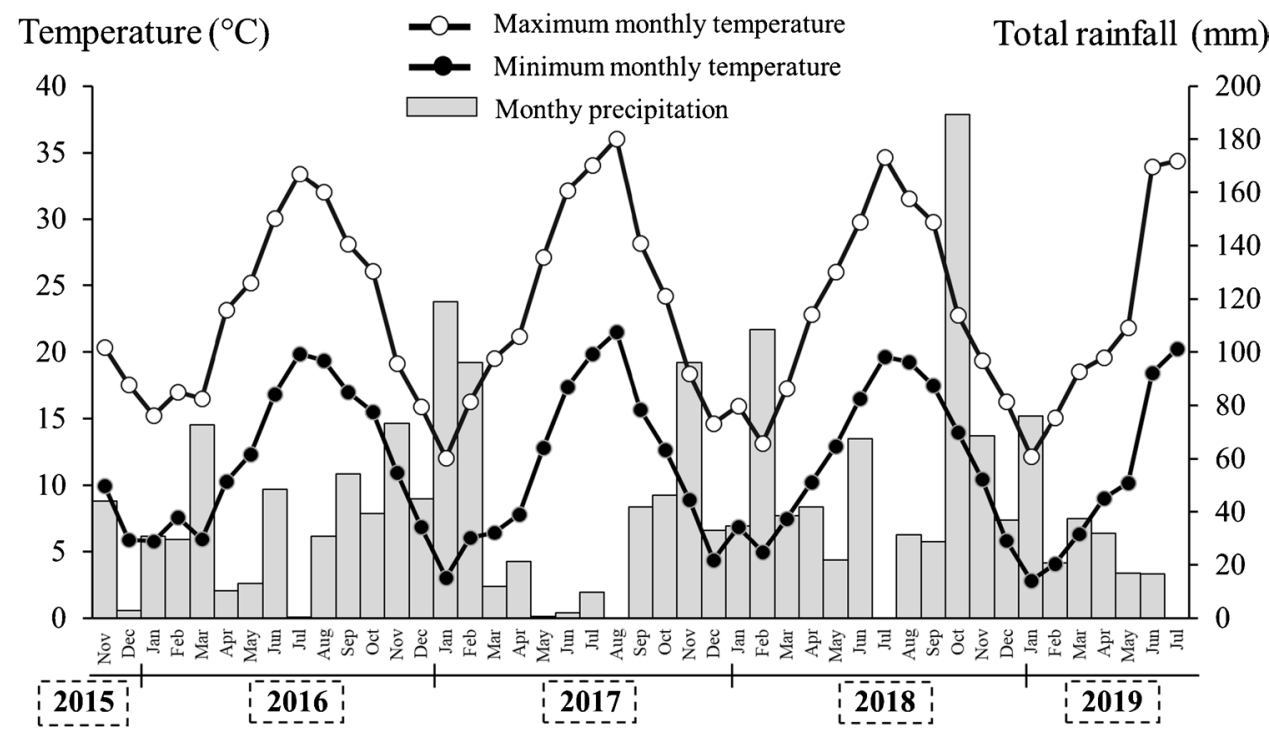




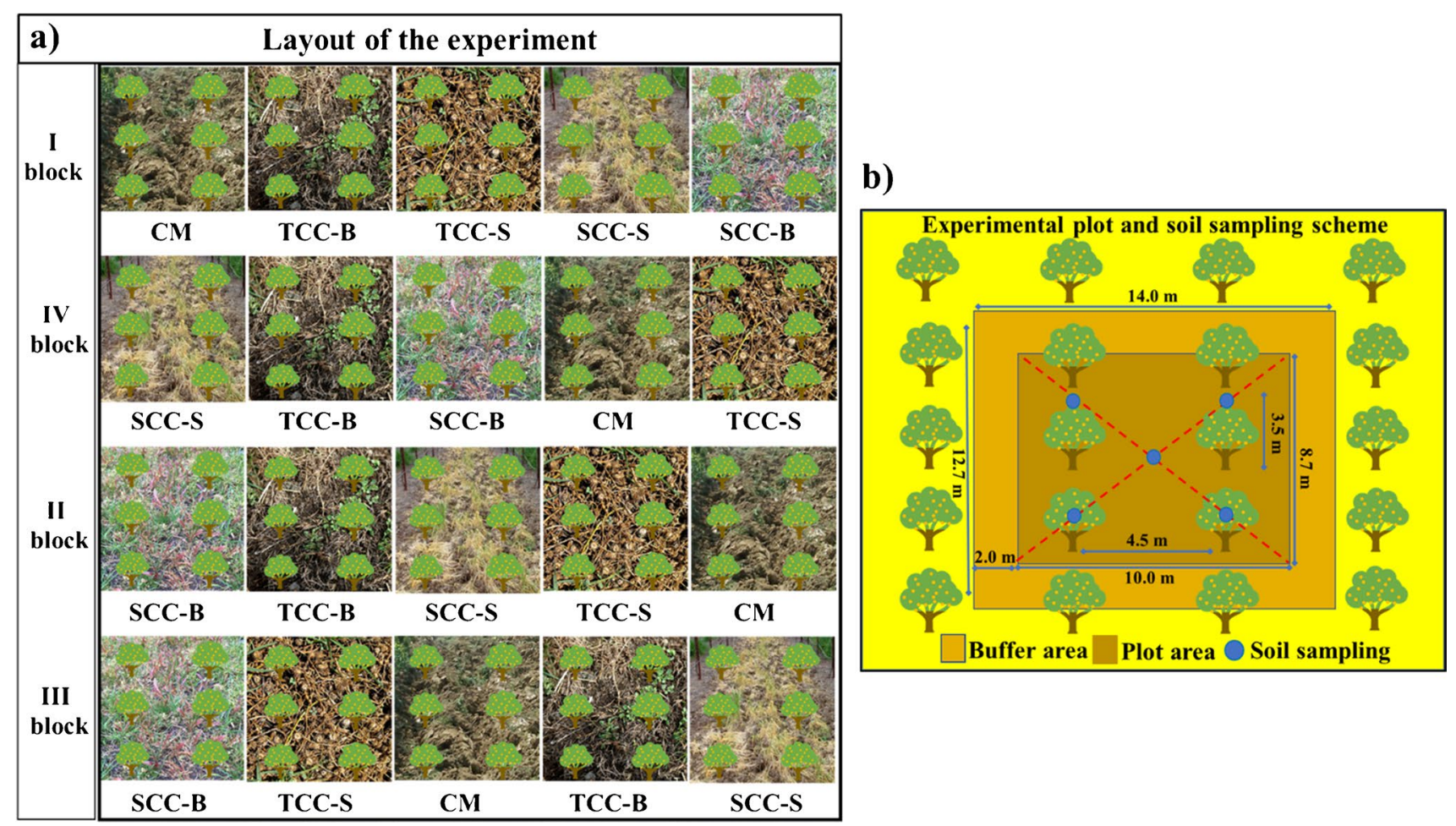

Fig. 3 (a) Schematic representation of the field experimental layout according to a randomized complete block design, and (b) detail of the experimental unit with scheme of soil sampling. Each soil sample is the sum of 5 subsamples per plot collected along the diagonals of the central part. CM, conventional apricot management; TCC-S, Tri-

during the experiment, apricot trees were 3.5-4.0-m high. Subterranean clover seeding was done in November 2015 by hand at 2-3-cm depth using 2000 germinable seeds $\mathrm{m}^{-2}$ of the cultivar 'Seaton Park', a common Australian early-mid season genotype presenting an autumn-winter-spring cycle and vernalization requirement for flowering. The length of the biological cycle (i.e., from the beginning of plant emergence until all the plants within a plot had completely dried up) was 200 days in season I, 220 days in season II, 250 in season III, and 240 in season IV (Restuccia et al. 2020). Its total biomass was $44 \mathrm{~g} \mathrm{DW} \mathrm{m}^{-2}$ in season I, $283 \mathrm{~g} \mathrm{DW} \mathrm{m}^{-2}$ in season II, $239 \mathrm{~g} \mathrm{DW} \mathrm{m}^{-2}$ in season III, and $159 \mathrm{~g} \mathrm{DW} \mathrm{m}^{-2}$ in season IV, thus confirming a good establishment of the cover crop after the self-reseeding (Restuccia et al. 2020). In all plots, in October, a shallow hoeing at $10-\mathrm{cm}$ deep followed by rigid tine harrowing was performed, together with a fertilization program consisting of $40 \mathrm{~kg} \mathrm{ha}^{-1} \mathrm{P}_{2} \mathrm{O}_{5}$, $14 \mathrm{~kg} \mathrm{ha}^{-1} \mathrm{~N}$, and $10 \mathrm{~kg} \mathrm{ha}^{-1} \mathrm{~K}_{2} \mathrm{O}$. Then, in each season, the following fertilizers were provided through fertirrigation from the developing apricot fruit phase until harvesting: $300 \mathrm{~kg} \mathrm{ha}^{-1}$ Ponimag® $\left(11 \% \mathrm{~N}, 41 \% \mathrm{~K}_{2} \mathrm{O}\right.$ and $\left.3 \% \mathrm{MgO}\right)$, $50 \mathrm{~kg} \mathrm{ha}^{-1}$ simple perphosphate $\left(\mathrm{P}_{2} \mathrm{O}_{5}\right), 100 \mathrm{~kg} \mathrm{ha}^{-1}$ liquid $\mathrm{Ca}$, and $50 \mathrm{~kg} \mathrm{ha}^{-1}$ Hergoton Plus ${ }^{\circledR}(8 \%$ total organic $\mathrm{N}, 26 \%$ biologic C, and $44.45 \%$ total organic matter). folium subterraneum cover cropping leaving dead mulch on the soil surface; TCC-B, T. subterraneum cover cropping burying dead mulch in the soil; SCC-S, spontaneous flora cover cropping leaving dead mulch on the soil surface; SCC-B, spontaneous flora cover cropping burying dead mulch in the soil.

Self-compensating drip irrigation replacing $100 \%$ of the daily evapotranspiration and twice chopping per year for weed control (in early spring and mid-summer) were carried out. Incorporation of dead mulches in TCC-B and SCC-B was carried out in September of each season at $-15 \mathrm{~cm}$ soil depth by disc ploughing. Insect and fungal control were done by low-dose applications of captano, tebuconazole, propiconazole, and lambda-cyhalothrin only when required.

\subsection{Soil sampling and analyses}

Before each soil sampling, a field scouting was conducted to locate the sampling units by excluding the non-representative areas and the outer $3 \mathrm{~m}$ for each plot. Soil sampling was carried out using a core sampler by collecting 5 randomly distributed subsamples (each of $0.75 \mathrm{dm}^{3}$ ) along the diagonals of the central part per plot, which were pooled to form a composite sample. The following soil depths and times were adopted:

- Two depths (0-20 and 21-40 cm) in March of season II and season IV to determine the contents of soil organic matter and macro- and microelements 
- From top soil $(0-15 \mathrm{~cm})$ twice per season [March $\left(\mathrm{T}_{1}\right)$ and June $\left(\mathrm{T}_{2}\right)$ ] to monitor the dynamics of the soil $\mathrm{N}$ mineral fractions $\left(\mathrm{NH}_{4}{ }^{+}\right.$and $\left.\mathrm{NO}_{3}{ }^{-}\right)$, in accordance with Scavo et al. (2020)

- From top soil $(0-15 \mathrm{~cm})$ twice per season [April $\left(\mathrm{T}_{1}\right)$ and September $\left.\left(\mathrm{T}_{2}\right)\right]$ for the weed seedbank

A total of 400 soil cores ( 20 plots $\times 2$ seasons $\times 2$ sampling depths or 2 sampling times $\times 5$ subsamples) was taken. Samples were collected in season II and IV to obtain a mid-term and a final evaluation.

Fresh soil samples were initially air-dried at room temperature for about 2 weeks, crushed, and sieved through a $2-\mathrm{mm}$ mesh sieve before laboratory analyses. The exchangeable cations $(\mathrm{K}, \mathrm{Ca}, \mathrm{Mg})$ were determined following the ISO 13,536 (1995) procedure while the available $\mathrm{P}_{2} \mathrm{O}_{5}$ according to the ISO 11,263 (1994) method. The soil organic carbon and total $\mathrm{N}$ analyses were conducted according to the ISO 14,235 (1998) and ISO 11,261 (1995) methods, respectively. The $\mathrm{N}$ mineral fractions were determined in the extractable $10 \mathrm{~g}$ soil samples treated with $50 \mathrm{ml}$ of $0.5 \mathrm{M} \mathrm{K}_{2} \mathrm{SO}_{4}$ into $250-\mathrm{ml}$ bottles. After $1 \mathrm{~h}$ shake, filtration with glass fiber Whatman GF/A and $0.45-\mu \mathrm{m}$ millipore filter, and centrifugation for $15 \mathrm{~min}$ at $3000 \mathrm{rpm}$, the ammoniacal $\left(\mathrm{NH}_{4}^{+}\right)$and nitric $\left(\mathrm{NO}_{3}{ }^{-}\right)$ $\mathrm{N}$-levels of the extracts were colorimetrically measured by diffusion (Crooke and Simpson 1971). The bioavailable fraction of the main micronutrients $(\mathrm{Cu}, \mathrm{Fe}, \mathrm{Mn}, \mathrm{Zn})$ was measured after extraction with buffered diethylenetriaminepentaacetic acid (DTPA) solution following the Lindsay and Norvell (1978) method.

\subsection{Analysis of the soil weed seedbank}

The analysis of the soil weed seedbank followed Scavo et al. (2019a). Firstly, 20 soil samples from each treatment (5 subsamples $\times 4$ replicates) were mixed giving a final volume of $15 \mathrm{dm}^{3}$, and then they were freed from inert components such as stones, pebbles, and dead debris. Secondly, seeds were separated from soil by using a metal tube (Karcher, K 3500 model, Winnenden, Germany) working at 20-120 bar adjustable washer pressure and equipped with a removable cap consisting of a steel mesh of $250 \mu \mathrm{m}$. Thirdly, weed counts and identification were performed in Petri dishes after $24 \mathrm{~h}$ air-drying with a MS5 Leica stereomicroscope (Leica Microsystems, Wetzlar, Germany). Seed identification and grouping followed Conti et al. (2005), while the seedbank size was calculated as the number of seeds $\mathrm{m}^{-2}$ for each plot.

In accordance with Nkoa et al. (2015) and Scavo et al. (2020), the soil weed seedbank was analyzed taking account both species abundance and diversity. Abundance was measured considering the seedbank size (number of weed seeds $\mathrm{m}^{-2}$ ), relative density (RD), relative frequency (RF), and the relative abundance index (RAI):

$R D(\%)=\left(\frac{\sum Y_{i}}{S}\right) \times 100$

$R F(\%)=\left(\frac{F_{i}}{\sum F}\right) \times 100$

$R A I(\%)=\frac{R D+R F}{2}$

where $\sum Y_{i}=$ sum of the number of seeds for a weed species; $S=$ total number of weed seeds within the plot; $F_{i}=$ absolute frequency of a species (i.e., number of sampling units in which the species $i$ occurred) $i$; and $\sum F=$ sum of the absolute frequencies of all species.

Richness and evenness were used to describe the withincommunity species diversity ( $\alpha$-diversity) (Travlos et al. 2018). Species richness was calculated as the total number of weed seeds counted in the five soil cores for each plot (Moonen and Bàrberi 2004), while evenness was estimated by computing the Shannon-Wiener $\left(\mathrm{H}^{\prime}\right)$ and the Pielous $(\mathrm{J})$ diversity indices, as suggested by Adeux et al. (2019):

$H^{\prime}=\sum\left[-p_{i}\left(\ln p_{i}\right)\right]$

$J=\frac{H^{\prime}}{H^{\prime}{ }_{\text {max }}}$

where $p_{i}=$ proportional abundance of the $i^{\text {th }}$ species; and $H^{\prime}{ }_{\max }=\operatorname{logarithm}$ of species richness.

\subsection{Statistical analysis}

For each soil variable, analysis of variance (ANOVA) was used to evaluate the effect of studied factors and their interaction. In particular, a generalized linear mixed model (GLMM) was applied considering "cover cropping" and "sampling depth" as fixed factors and "season" as random factor (Gomez and Gomez 1984). At each season, oneway ANOVAs were performed (one with "cover cropping" and another with "sampling depth"). Moreover, in order to observe the overall effect of cover cropping on each soil variable under study, one-way ANOVAs was carried out by pooling data over seasons and sampling depths. The ANOVA basic assumptions of homoscedasticity and normality were checked by graphically inspecting the residuals, which showed no significant deviations, together with the Bartlett's test. Post hoc comparison of means was performed through the Fisher's protected least significant difference 
(LSD) test at $\alpha=0.05$ by using the statistical package CoStat ${ }^{\circledR} 6.003$ (CoHort Software, Monterey, CA, USA).

Soil seedbank data, species richness, RAI data, and diversity indices were subjected to two-way ANOVAs ("cover cropping" $\times$ "sampling time") for each season. Prior to ANOVA, data about seedbank size needed log transformation, whereas an arcsine-square root transformation was used for RAI of major weeds. Moreover, $\mathrm{H}^{\prime}$ and $\mathrm{J}$ data were square root and logit-transformed, respectively. Data on species richness did not need any transformation before ANOVA. Multivariate statistics was conducted to analyze the weed species composition. In each season, multivariate analysis of variance (MANOVA) on $\log _{\mathrm{e}}(\mathrm{x}+1)$-transformed data was carried out to evaluate the effect on variance of cover cropping, sampling time, and their interaction. Significance levels in MANOVA were determined according to Wilks' criterion. The effects of MANOVA were visualized by applying a principal component analysis (PCA) on 8 major weeds, considering the means for each "cover cropping $\times$ sampling time" combination. PCA was performed on the covariance matrix of $\log _{\mathrm{e}}(\mathrm{x}+1)$-transformed density data, and the results were displayed on "distance" biplots (Legendre and Legendre 2012). The computer package Minitab ${ }^{\circledR}$ version 16 (Minitab Inc., State College, PA, USA) was used to perform both MANOVA and PCA.

\section{Results}

\subsection{Cover-cropping effects on soil organic matter, macro- and microelements}

ANOVA demonstrated a significant effect of cover cropping on SOM and soil nutrient content, even if with seasonaldependent results. From the one-way ANOVA applied on 'cover cropping' and pooling over seasons and sampling depths (Fig. 4), emerged that TCC-B significantly increased the amount of SOM by $15 \%$, total $\mathrm{N}$ by $7 \%$, exchangeable $\mathrm{K}_{2} \mathrm{O}$ by $14 \%$, exchangeable Na by $32 \%$, exchangeable $\mathrm{K}$ by $16 \%$, Fe by $15 \%$, Mn by $28 \%, \mathrm{Zn}$ by $36 \%$ and $\mathrm{Cu}$ by $24 \%$, as compared to those of $\mathrm{CM}$. The highest levels of assimilable $\mathrm{P}_{2} \mathrm{O}_{5}$ were found in SCC-B $\left(39.8 \mathrm{mg} \mathrm{kg}^{-1}\right)$ and SCC-S $\left(32.7 \mathrm{mg} \mathrm{kg}^{-1}\right)$. Also, SCC-B and SCC-S showed significant increments in SOM and soil macro- and microelement levels with respect to $\mathrm{CM}$, while TCC-S was interestingly associated with lower amounts of total $\mathrm{N}(-4 \%)$, assimilable $\mathrm{P}_{2} \mathrm{O}_{5}(-26 \%)$, exchangeable $\mathrm{K}_{2} \mathrm{O}(-5 \%)$, exchangeable $\mathrm{K}$ $(-3 \%)$, and $\mathrm{Cu}(-17 \%)$, as compared to $\mathrm{CM}$ (Fig. 4). CEC, on average equal to $\sim 50 \mathrm{meq} 100 \mathrm{~g}^{-1}$ throughout the four seasons, was not influenced by factors under study (data not shown). Ca was the prevailing exchangeable cation $(\sim 88 \%$ of CEC), followed in decreasing order by $\mathrm{Mg}(\sim 9 \%), \mathrm{Na}$ $(\sim 2 \%)$, and $\mathrm{K}(\sim 1 \%)$. No significant differences among treatments were observed for exchangeable $\mathrm{Ca}$ and $\mathrm{Mg}$ concentrations, while exchangeable $\mathrm{Na}$ and $\mathrm{K}$ were influenced by cover cropping type.

In season II, the GLMM showed how cover cropping had high significance on all the soil variables, except for total $\mathrm{N}$ and exchangeable $\mathrm{Mg}$ (Table 1). In particular, regardless of sampling depth, the highest levels of SOM were detected in SCC-S and TCC-B $(+13 \%$ and $+10 \%$ than CM, respectively), the highest concentrations of assimilable $\mathrm{P}_{2} \mathrm{O}_{5}$ in SCC-S (+15\%, even if not statistically significant) and the highest ones of exchangeable $\mathrm{K}_{2} \mathrm{O}$ in TCC-B $(+15 \%)$, of exchangeable $\mathrm{Ca}$ in SCC-B and SCC-S $(+7 \%$ and $+5 \%$, respectively), of exchangeable $\mathrm{Na}$ in SCC-B and SCC-S $(+51 \%$ and $+48 \%$, respectively), and of exchangeable $\mathrm{K}$ in TCC-B $(+17 \%)$ (Table 1). Concerning soil microelements (Table 2), SCC-S promoted the highest concentration of $\mathrm{Mn}\left(7.97 \mathrm{mg} \mathrm{kg}^{-1}\right), \mathrm{Zn}\left(0.22 \mathrm{mg} \mathrm{kg}^{-1}\right)$, and $\mathrm{Cu}$ (3.18 $\mathrm{m} \mathrm{kg}^{-1}$ ), while Fe-level was the highest in SCC-B $\left(9.55 \mathrm{mg} \mathrm{kg}^{-1}\right)$. Higher amounts of soil microelements than CM were found also in TCC-B, whereas TCC-S caused a decrease. No significant differences were observed regarding soil layers, except for exchangeable $\mathrm{K}_{2} \mathrm{O}$ and exchangeable $\mathrm{Na}$. The two-way interaction "cover cropping $\times$ sampling depth" was significant only for SOM, exchangeable $\mathrm{K}_{2} \mathrm{O}$, exchangeable $\mathrm{Na}$, exchangeable $\mathrm{K}$, and $\mathrm{Fe}$ (Tables 1 and 2). In this view, except for exchangeable $\mathrm{Na}$ and $\mathrm{Fe}, \mathrm{TCC}-\mathrm{B}$ and SCC-S performed better in the $0-20-\mathrm{cm}$ soil layer than in the $21-40 \mathrm{~cm}$ one.

The cumulated cover cropping effects of season IV on the above-mentioned soil variables were more marked than those of season II. Indeed, GLMM indicated that TCC-B ensured a significant increase, compared to $\mathrm{CM}$, in the amount of SOM $(+19 \%)$, total N $(+17 \%)$, exchangeable $\mathrm{K}_{2} \mathrm{O}(+13 \%)$, exchangeable $\mathrm{Na}(+30 \%)$, exchangeable $\mathrm{K}$ $(+27 \%), \mathrm{Fe}(+12 \%), \mathrm{Mn}(+46 \%), \mathrm{Zn}(+52 \%)$, and $\mathrm{Cu}$ $(+36 \%)$ (Tables 1 and 2). Spontaneous flora cover cropping (SCC-B and SCC-S) provided the highest content of assimilable $\mathrm{P}_{2} \mathrm{O}_{5}$ (58.2 and $42.0 \mathrm{mg} \mathrm{kg}^{-1}$, respectively) and $\mathrm{Mn}\left(8.1 \mathrm{mg} \mathrm{kg}^{-1}\right)$, whereas exchangeable $\mathrm{Ca}$ and $\mathrm{Mg}$ did not differ significantly, as observed in season II. Moreover, in this season, the effect of sampling depth was generally significant, except for exchangeable $\mathrm{Ca}$, exchangeable $\mathrm{Mg}$, exchangeable $\mathrm{Na}, \mathrm{Fe}$, and $\mathrm{Mn}$. The $0-20-\mathrm{cm}$ soil layer showed higher amounts of SOM $(+19.5 \%)$, total N $(+11.4 \%)$, assimilable $\mathrm{P}_{2} \mathrm{O}_{5}(+139 \%)$, exchangeable $\mathrm{K}_{2} \mathrm{O}$ $(+34 \%)$, exchangeable $\mathrm{K}(+35 \%), \mathrm{Zn}(+46 \%)$, and $\mathrm{Cu}$ $(+53 \%)$ than the $21-40 \mathrm{~cm}$ one. 


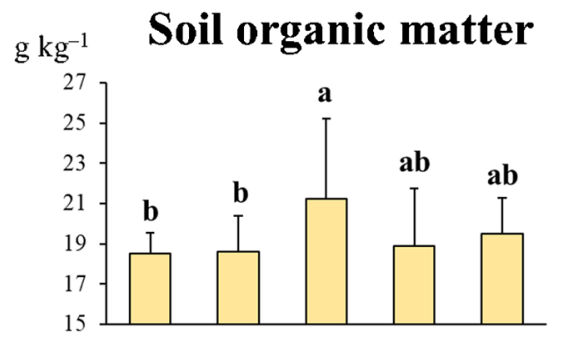

Exchangeable $\mathrm{K}_{2} \mathrm{O}$

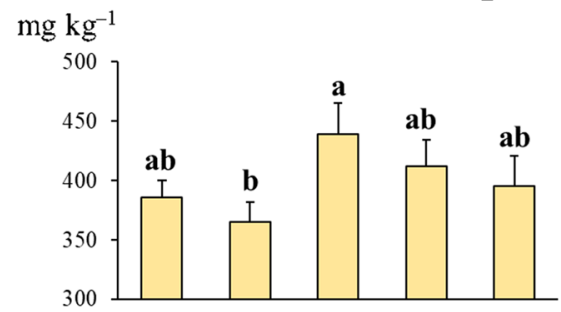

Exchangeable Na
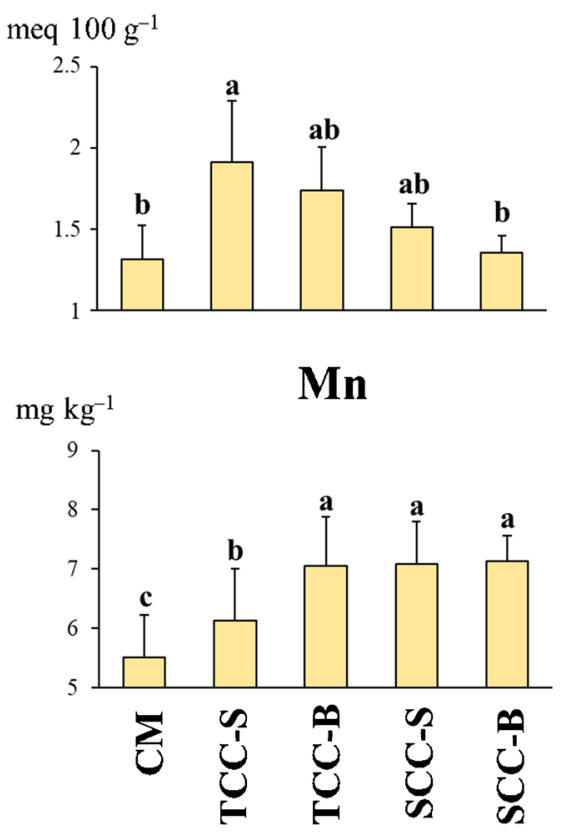

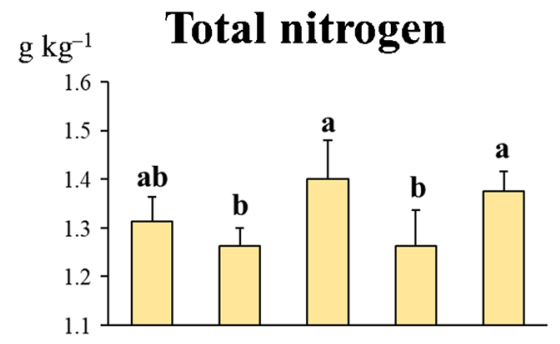

Exchangeable Ca

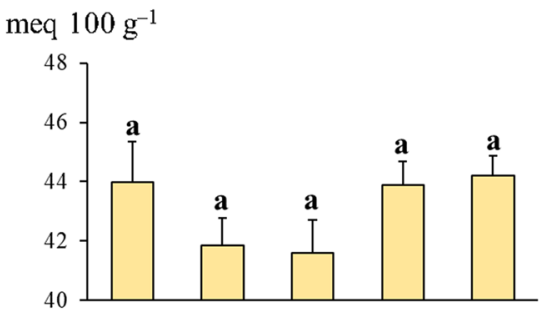

Exchangeable K
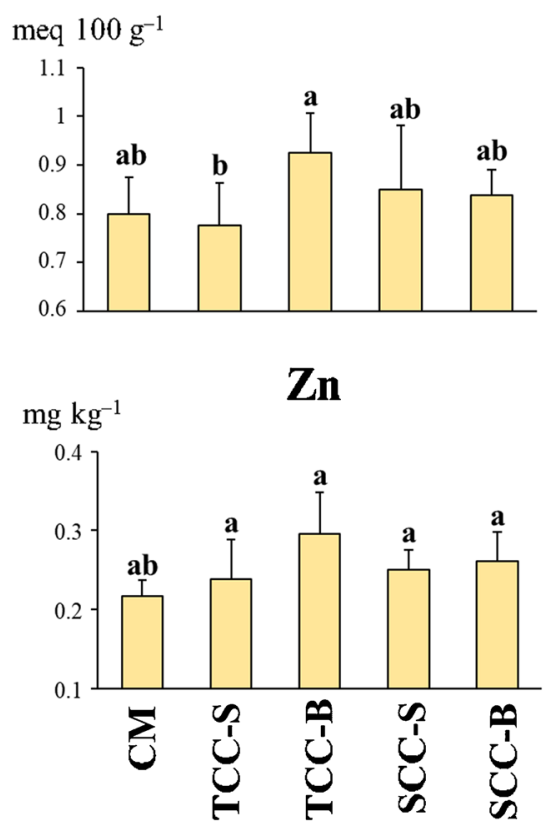

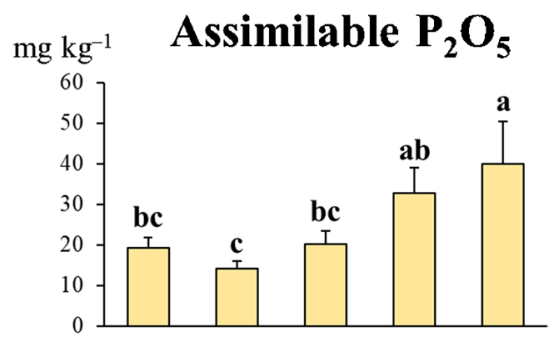

Exchangeable Mg

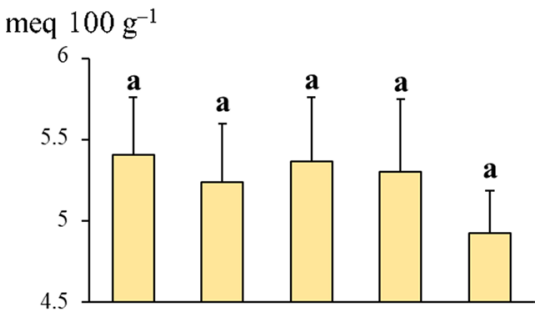

$\mathrm{Fe}$

$\mathrm{mg} \mathrm{kg}^{-1}$

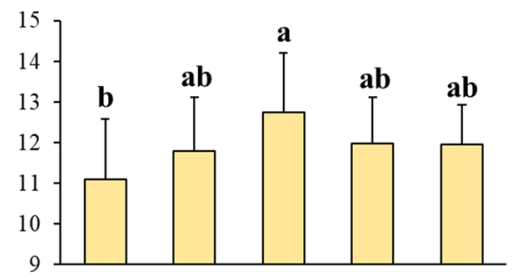

$\mathrm{Cu}$

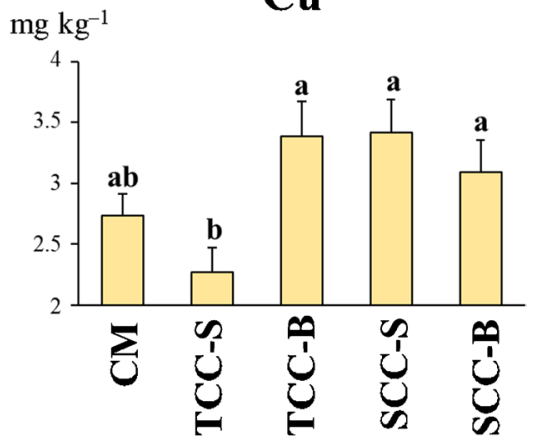

Fig. 4 Effect of cover-cropping, pooling over seasons, and soil sampling depths, on organic matter and macro- and micro-elements. Bars are standard error of the mean (SEM, $n=8$ ). Different letters indicate statistical significance by applying a one-way analysis of variance with LSD test at $P \leq 0.05$. CM, conventional apricot management;

\subsection{Cover-cropping effects on soil mineral nitrogen dynamics}

The GLMM indicated that the effect of cover cropping was highly significant $(P \leq 0.001)$ for both mineral $\mathrm{N}$ forms and in both seasons, while the sampling time was significant only in season IV (Table 2). Subterranean clover cover cropping always showed the highest levels of total soil mineral N, with
TCC-S, Trifolium subterraneum cover cropping leaving dead mulch on the soil surface; TCC-B, T. subterraneum cover cropping burying dead mulch in the soil; SCC-S, spontaneous flora cover cropping leaving dead mulch on the soil surface; SCC-B, spontaneous flora cover cropping burying dead mulch in the soil.

TCC-S better performing in season II and TCC-B in season IV. Averaged over sampling times (March and June), in season II, TCC-B determined an increase of $148 \%$ in soil $\mathrm{NH}_{4}{ }^{+}$and $244 \%$ in soil $\mathrm{NO}_{3}{ }^{-}$, compared to CM. Such positive effect became stronger in season IV, especially for $\mathrm{NH}_{4}{ }^{+}$, with $\mathrm{a}+194 \%$ than $\mathrm{CM}$ and $+133 \%$ than the same treatment in season II. Also, the soil from SCC-S and SCC-B plots contained more mineral $\mathrm{N}$ than $\mathrm{CM}(+49$ and $+76 \%$, respectively). The 
Table 1 Effect of cover cropping (CC) and soil sampling depth (SD) on organic matter (SOM), macroelements, and exchangeable bases with analysis of variance (ANOVA, $P$ values). Values are means $(n=2)$ with standard deviation (in brackets). Values within a column followed by the same letters are not significantly different at $P \leq 0.05$ (LSD test). CM conventional apricot management, TCC-S Trifolium subterraneum cover cropping leaving dead mulch on the soil surface, TCC-B T. subterraneum cover cropping burying dead mulch in the soil, SCC-S spontaneous flora cover cropping leaving dead mulch on the soil surface, SCC-B spontaneous flora cover cropping burying dead mulch in the soil, season II 2016/2017, season IV 2018/2019.

\begin{tabular}{|c|c|c|c|c|c|c|c|c|c|}
\hline \multirow[t]{2}{*}{ Treatment } & & \multicolumn{2}{|l|}{$\operatorname{SOM}\left(\mathrm{g} \mathrm{kg}^{-1}\right)$} & \multicolumn{2}{|c|}{ Total $\mathrm{N}\left(\mathrm{g} \mathrm{kg}^{-1}\right)$} & \multicolumn{2}{|c|}{ Assimilable $\mathrm{P}_{2} \mathrm{O}_{5}\left(\mathrm{mg} \mathrm{kg}^{-1}\right)$} & \multicolumn{2}{|c|}{ Exchangeable $\mathrm{K}_{2} \mathrm{O}\left(\mathrm{mg} \mathrm{kg}^{-1}\right)$} \\
\hline & & Season II & Season IV & Season II & Season IV & Season II & Season IV & Season II & Season IV \\
\hline \multirow[t]{5}{*}{$\mathrm{CC}$} & $\mathrm{CM}$ & $\begin{array}{l}18.38(0.48) \\
\text { bc }\end{array}$ & $\begin{array}{l}18.63(1.49) \\
\text { bc }\end{array}$ & $1.32(0.21) \mathrm{a}$ & $\begin{array}{l}1.30(0.08) \\
\mathrm{bc}\end{array}$ & $20.4(5.6) \mathrm{a}$ & $18.0(9.9) \mathrm{c}$ & $\begin{array}{l}368.0(46.1) \\
\mathrm{b}\end{array}$ & $403.9(28.1) b c$ \\
\hline & TCC-S & $17.75(0.96) \mathrm{c}$ & $\begin{array}{l}19.50(2.08) \\
\mathrm{b}\end{array}$ & $1.27(0.10) \mathrm{a}$ & $1.25(0.13) \mathrm{c}$ & $14.5(1.7) \mathrm{b}$ & $14.0(5.1) \mathrm{c}$ & $\begin{array}{l}329.5(11.4) \\
\mathrm{c}\end{array}$ & $401.5(37.0) \mathrm{c}$ \\
\hline & TCC-B & $\begin{array}{l}20.25(1.50) \\
\mathrm{ab}\end{array}$ & $22.25(5.62) \mathrm{a}$ & $1.27(0.05) \mathrm{a}$ & $1.52(0.28) \mathrm{a}$ & $21.7(1.7) \mathrm{a}$ & $18.5(9.8) b$ & $\begin{array}{l}421.7(53.0) \\
\mathrm{a}\end{array}$ & $456.5(95.5) \mathrm{a}$ \\
\hline & SCC-S & $20.75(2.75) \mathrm{a}$ & $17.0(1.41) \mathrm{c}$ & $1.17(0.28) \mathrm{a}$ & $\begin{array}{l}1.35(0.06) \\
\mathrm{bc}\end{array}$ & $23.5(2.9) \mathrm{a}$ & $42.0(15.8) \mathrm{a}$ & $\begin{array}{l}382.7(40.5) \\
b\end{array}$ & $441.5(72.1) \mathrm{ab}$ \\
\hline & SCC-B & $\begin{array}{l}19.75(2.50) \\
\text { abc }\end{array}$ & $\begin{array}{l}19.25(0.96) \\
b\end{array}$ & $1.30(0.08) \mathrm{a}$ & $\begin{array}{l}1.45(0.10) \\
\mathrm{ab}\end{array}$ & $21.5(2.5) \mathrm{a}$ & $58.2(23.8) \mathrm{a}$ & $\begin{array}{l}370.5(31.4) \\
\mathrm{b}\end{array}$ & $\begin{array}{l}420.2(68.4) \\
\text { abc }\end{array}$ \\
\hline \multirow[t]{2}{*}{ SD } & $0-20 \mathrm{~cm}$ & $19.66(2.08) \mathrm{a}$ & $21.05(3.42) \mathrm{a}$ & $1.32(0.15) \mathrm{a}$ & $1.45(0.18) \mathrm{a}$ & $20.5(4.9) \mathrm{a}$ & $42.5(25.4) \mathrm{a}$ & $\begin{array}{l}392.3(53.1) \\
\text { a }\end{array}$ & $486.7(57.8) \mathrm{a}$ \\
\hline & $21-40 \mathrm{~cm}$ & $19.10(2.02) \mathrm{a}$ & $\begin{array}{l}17.60(1.35) \\
\mathrm{b}\end{array}$ & $1.22(0.15) b$ & $1.30(0.12) b$ & $20.2(3.8) \mathrm{a}$ & $17.8(8.5) b$ & $\begin{array}{l}356.7(31.5) \\
\mathrm{b}\end{array}$ & $362.8(28.2) b$ \\
\hline \multirow[t]{3}{*}{ ANOVA } & $\mathrm{CC}$ & 0.0345 & 0.0024 & 0.6188 & 0.0207 & 0.0474 & 0.0004 & 0.0028 & 0.0343 \\
\hline & SD & 0.3556 & $<0.001$ & 0.1358 & 0.0084 & 0.8815 & 0.0003 & 0.0055 & $<0.001$ \\
\hline & $\mathrm{CC} \times \mathrm{SD}$ & 0.0151 & 0.0049 & 0.1376 & 0.1812 & 0.7902 & 0.0291 & 0.0118 & 0.0017 \\
\hline \multirow[t]{2}{*}{ Treatment } & & \multicolumn{2}{|c|}{$\begin{array}{l}\text { Exchangeable Ca (meq } \\
100 \mathrm{~g}^{-1} \text { ) }\end{array}$} & \multicolumn{2}{|c|}{$\begin{array}{l}\text { Exchangeable } \mathrm{Mg} \text { (meq } \\
100 \mathrm{~g}^{-1} \text { ) }\end{array}$} & \multicolumn{2}{|c|}{$\begin{array}{l}\text { Exchangeable Na (meq } \\
100 \mathrm{~g}^{-1} \text { ) }\end{array}$} & \multicolumn{2}{|c|}{$\begin{array}{l}\text { Exchangeable K (meq } \\
100 \mathrm{~g}^{-1} \text { ) }\end{array}$} \\
\hline & & Season II & Season IV & Season II & Season IV & Season II & Season IV & Season II & Season IV \\
\hline \multirow[t]{5}{*}{$\mathrm{CC}$} & $\mathrm{CM}$ & 41.7 (0.7)ab & $46.3(4.5) \mathrm{a}$ & $4.55(0.56) \mathrm{a}$ & $\begin{array}{l}6.25(0.37) \\
\mathrm{ab}\end{array}$ & $0.83(0.04) \mathrm{d}$ & $\begin{array}{l}1.80(0.49) \\
\mathrm{bc}\end{array}$ & $\begin{array}{l}0.75(0.03) \\
\mathrm{bc}\end{array}$ & $0.85(0.02) b$ \\
\hline & TCC-S & $40.2(1.0) \mathrm{b}$ & $43.4(2.8) \mathrm{a}$ & $4.32(0.10) \mathrm{a}$ & $\begin{array}{l}6.15(0.48) \\
\mathrm{ab}\end{array}$ & $0.93(0.05) \mathrm{c}$ & $2.90(0.64) \mathrm{a}$ & $0.70(0.06) \mathrm{c}$ & $0.85(0.02) \mathrm{b}$ \\
\hline & TCC-B & $40.5(4.0) b$ & $42.6(1.8) \mathrm{a}$ & $4.32(0.22) \mathrm{a}$ & $6.40(0.08) \mathrm{a}$ & $1.13(0.09) \mathrm{b}$ & $\begin{array}{l}2.35(0.50) \\
\mathrm{ab}\end{array}$ & $0.88(0.04) \mathrm{a}$ & $0.98(0.11) a$ \\
\hline & SCC-S & $44.0(1.7) \mathrm{a}$ & $43.6(2.9) \mathrm{a}$ & $4.20(0.18) \mathrm{a}$ & $6.40(0.71) \mathrm{a}$ & $1.23(0.04) \mathrm{a}$ & $\begin{array}{l}1.80(0.28) \\
\mathrm{bc}\end{array}$ & $0.78(0.04) b$ & $0.93(0.04) \mathrm{ab}$ \\
\hline & SCC-B & $44.5(0.6) \mathrm{a}$ & $46.9(2.8) \mathrm{a}$ & $4.25(0.17) \mathrm{a}$ & $5.60(0.18) \mathrm{b}$ & $1.25(0.11) \mathrm{a}$ & $1.45(0.49) \mathrm{c}$ & $0.80(0.07) \mathrm{b}$ & $0.88(0.04) b$ \\
\hline \multirow[t]{2}{*}{ SD } & $0-20 \mathrm{~cm}$ & $42.3(1.6) \mathrm{a}$ & $44.8(3.1) \mathrm{a}$ & $4.39(0.38) \mathrm{a}$ & $6.06(0.46) \mathrm{a}$ & $1.03(0.05) b$ & $1.88(0.42) \mathrm{a}$ & $0.80(0.03) \mathrm{a}$ & $1.03(0.6) \mathrm{a}$ \\
\hline & $21-40 \mathrm{~cm}$ & $42.0(3.4) \mathrm{a}$ & $43.3(3.0) \mathrm{a}$ & $4.28(0.17) \mathrm{a}$ & $6.26(0.51) \mathrm{a}$ & $1.11(0.12) \mathrm{a}$ & $2.24(0.54) \mathrm{a}$ & $0.76(0.05) \mathrm{a}$ & $0.76(0.03) b$ \\
\hline \multirow[t]{3}{*}{ ANOVA } & $\mathrm{CC}$ & 0.0363 & 0.6250 & 0.5231 & 0.1698 & $<0.001$ & 0.0230 & 0.0031 & 0.0548 \\
\hline & SD & 0.7466 & 0.3262 & 0.4535 & 0.3607 & 0.0085 & 0.1605 & 0.0734 & $<0.001$ \\
\hline & $\mathrm{CC} \times \mathrm{SD}$ & 0.3387 & 0.6692 & 0.4669 & 0.8113 & 0.0034 & 0.4499 & 0.0226 & 0.0015 \\
\hline
\end{tabular}

two-way interaction and the sampling time were significant at $P \leq 0.001$ in season IV, with higher values of $\mathrm{NH}_{4}{ }^{+}, \mathrm{NO}_{3}{ }^{-}$and their sum in the June sampling than the March one.

\subsection{Cover-cropping effects on the weed soil seedbank}

Over the two seasons under study, the $0-15$-cm soil seedbank was composed of 22 taxa in total, mainly Asteraceae members (32\%), annual (77\%), and therophytes (77\%) (Table 3). Sonchus sp., Anagallis arvensis L., and Phalaris paradoxa $\mathrm{L}$. had the highest relative abundance values. Centaurea napifolia $\mathrm{L}$. had the higher relative abundance values in season IV than in season II, while Portulaca oleracea $\mathrm{L}$. showed an opposite trend. No consistent trends were observed for the other weeds. Nevertheless, the effect of cover cropping on species richness was inconsistent, and, for this reason, these data were not shown. Among the 22 
Table 2 Effect of cover cropping (CC) and soil sampling depth (SD) on major microelements and ammoniacal $\left(\mathrm{NH}_{4}{ }^{+}\right)$and nitric $\left(\mathrm{NO}_{3}{ }^{-}\right)$ nitrogen with analysis of variance (ANOVA, $P$ values). Values are means ( $n=2$ for soil microelements and $n=3$ for mineral nitrogen) with standard deviation (in brackets). Values within a column followed by the same letters are not significantly different at $P \leq 0.05$
(LSD test). CM conventional apricot management, TCC-S Trifolium subterraneum cover cropping leaving dead mulch on the soil surface, TCC-B T. subterraneum cover cropping burying dead mulch in the soil, SCC-S spontaneous flora cover cropping leaving dead mulch on the soil surface, SCC-B spontaneous flora cover cropping burying dead mulch in the soil, season II 2016/2017, season IV 2018/2019.

\begin{tabular}{|c|c|c|c|c|c|c|c|c|c|}
\hline \multirow[t]{2}{*}{ Treatment } & & \multicolumn{2}{|l|}{$\mathrm{Fe}\left(\mathrm{mg} \mathrm{kg}^{-1}\right)$} & \multicolumn{2}{|l|}{$\operatorname{Mn}\left(\mathrm{mg} \mathrm{kg}^{-1}\right)$} & \multicolumn{2}{|l|}{$\mathrm{Zn}\left(\mathrm{mg} \mathrm{kg}^{-1}\right)$} & \multicolumn{2}{|l|}{$\mathrm{Cu}\left(\mathrm{mg} \mathrm{kg}^{-1}\right)$} \\
\hline & & Season II & Season IV & Season II & Season IV & Season II & Season IV & Season II & Season IV \\
\hline \multirow[t]{5}{*}{$\mathrm{CC}$} & $\mathrm{CM}$ & $7.75(0.56) b$ & $14.42(3.44) b$ & $5.57(1.52) b c$ & $5.46(2.24) b$ & $0.19(0.02) a b$ & $0.25(0.07) b$ & $2.79(0.49) a b$ & $2.68(0.62) \mathrm{b}$ \\
\hline & TCC-S & $8.40(0.05) \mathrm{b}$ & $15.18(1.39) \mathrm{b}$ & $4.41(0.88) \mathrm{c}$ & $7.85(2.35) a$ & $0.13(0.03) \mathrm{b}$ & $0.35(0.11) \mathrm{ab}$ & $1.76(0.05) \mathrm{c}$ & $2.77(0.33) \mathrm{b}$ \\
\hline & TCC-B & $9.33(0.31) \mathrm{a}$ & $16.16(3.10) \mathrm{a}$ & $6.14(0.75) b c$ & 7.97 (3.09)a & $0.21(0.03) \mathrm{a}$ & $0.38(0.18) \mathrm{a}$ & $3.12(0.22) \mathrm{ab}$ & $3.65(1.59) \mathrm{a}$ \\
\hline & SCC-S & $9.29(1.02) \mathrm{a}$ & $14.68(1.89) \mathrm{b}$ & $7.97(0.95) \mathrm{a}$ & $6.17(2.55) \mathrm{ab}$ & $0.22(0.03) \mathrm{a}$ & $0.29(0.09) \mathrm{ab}$ & $3.18(0.29) \mathrm{a}$ & $3.66(1.20) \mathrm{a}$ \\
\hline & SCC-B & $9.55(1.27) \mathrm{a}$ & $14.35(0.92) b$ & $6.16(0.28) b$ & $8.10(0.91) a$ & $0.19(0.02) \mathrm{ab}$ & $0.34(0.10) \mathrm{ab}$ & $2.60(0.28) b$ & $3.58(0.78) \mathrm{a}$ \\
\hline \multirow[t]{2}{*}{ SD } & $0-20 \mathrm{~cm}$ & $8.76(1.06) \mathrm{a}$ & $14.92(2.15) \mathrm{a}$ & $5.83(2.12) \mathrm{a}$ & $7.90(2.24) \mathrm{a}$ & $0.19(0.05) \mathrm{ab}$ & $0.38(0.13) \mathrm{a}$ & $2.66(0.59) \mathrm{a}$ & $3.95(0.98) \mathrm{a}$ \\
\hline & $21-40 \mathrm{~cm}$ & $8.97(0.96) \mathrm{a}$ & $15.00(2.37) \mathrm{a}$ & $6.28(0.81) \mathrm{a}$ & $6.30(2.31) \mathrm{a}$ & $0.18(0.03) \mathrm{ab}$ & $0.26(0.05) \mathrm{b}$ & $2.72(0.62) \mathrm{a}$ & $2.58(0.35) \mathrm{b}$ \\
\hline \multirow[t]{3}{*}{ ANOVA } & $\mathrm{CC}$ & 0.0024 & 0.0010 & 0.0142 & 0.0127 & 0.0006 & 0.0427 & 0.0012 & 0.0316 \\
\hline & SD & 0.3930 & 0.7060 & 0.3866 & 0.1129 & 0.2551 & 0.0046 & 0.7092 & $<0.001$ \\
\hline & $\mathrm{CC} \times \mathrm{SD}$ & 0.0090 & 0.9254 & 0.2651 & 0.2432 & 0.0369 & 0.0223 & 0.9091 & 0.0275 \\
\hline \multirow[t]{2}{*}{ Treatment } & & \multicolumn{2}{|l|}{$\mathrm{NH}_{4}^{+}(\mathrm{ppm})$} & \multicolumn{2}{|l|}{$\mathrm{NO}_{3}{ }^{-}(\mathrm{ppm})$} & \multicolumn{2}{|c|}{$\mathrm{NH}_{4}^{+}+\mathrm{NO}_{3}^{-}(\mathrm{ppm})$} & & \\
\hline & & Season II & Season IV & Season II & Season IV & Season II & Season IV & & \\
\hline \multirow[t]{5}{*}{$\mathrm{CC}$} & $\mathrm{CM}$ & $2.64(0.86) \mathrm{d}$ & $5.17(0.33) \mathrm{d}$ & $5.22(1.23) \mathrm{d}$ & $5.03(0.43) \mathrm{e}$ & $7.86(1.66) \mathrm{d}$ & $10.20(0.67) \mathrm{e}$ & & \\
\hline & TCC-S & $7.61(0.94) \mathrm{a}$ & $15.66(0.46) \mathrm{a}$ & $18.51(1.12) \mathrm{a}$ & $18.73(0.45) b$ & $26.12(1.21) \mathrm{a}$ & $34.39(0.56) \mathrm{b}$ & & \\
\hline & TCC-B & $6.54(1.09) b$ & $15.22(0.53) \mathrm{a}$ & $17.98(1.14) \mathrm{a}$ & $20.54(0.54) \mathrm{a}$ & $24.52(1.25) \mathrm{a}$ & $35.76(0.90) \mathrm{a}$ & & \\
\hline & SCC-S & $3.91(0.31) \mathrm{c}$ & $5.87(0.55) \mathrm{c}$ & $11.38(1.60) \mathrm{b}$ & $9.31(0.52) \mathrm{d}$ & $15.29(1.84) \mathrm{b}$ & $15.17(0.54) \mathrm{d}$ & & \\
\hline & SCC-B & $3.71(0.34) \mathrm{cd}$ & $7.24(0.31) b$ & $9.38(1.54) \mathrm{c}$ & $10.68(0.59) \mathrm{c}$ & $13.10(1.67) \mathrm{c}$ & $17.91(0.89) \mathrm{c}$ & & \\
\hline \multirow[t]{2}{*}{ SD } & March & $4.48(0.68) \mathrm{b}$ & $7.81(0.41) b$ & $12.89(1.26) \mathrm{a}$ & $12.04(0.53) \mathrm{b}$ & $17.37(1.64) \mathrm{a}$ & $19.85(0.79) \mathrm{b}$ & & \\
\hline & June & $5.33(0.81) \mathrm{a}$ & $11.85(0.46) \mathrm{a}$ & $12.10(1.39) \mathrm{a}$ & $13.67(0.48) \mathrm{a}$ & $17.43(1.42) \mathrm{a}$ & $25.52(0.63) \mathrm{a}$ & & \\
\hline \multirow[t]{3}{*}{ ANOVA } & $\mathrm{CC}$ & $<0.001$ & $<0.001$ & $<0.001$ & $<0.001$ & $<0.001$ & $<0.001$ & & \\
\hline & $\mathrm{ST}$ & 0.0174 & $<0.001$ & 0.1485 & $<0.001$ & 0.9100 & $<0.001$ & & \\
\hline & $\mathrm{CC} \times \mathrm{ST}$ & 0.0854 & $<0.001$ & 0.1246 & $<0.001$ & 0.0703 & $<0.001$ & & \\
\hline
\end{tabular}

species and genera recorded, only a few evidenced high enough density to be included in the multivariate analysis for species composition. In particular, only for 8 taxa was an $\mathrm{RD}>4 \%$ (i.e., major weeds) found: Amaranthus retroflexus L., A. arvensis, C. napifolia, P. paradoxa, P. oleracea, Sinapis arvensis L., Sonchus sp., and Veronica cymbalaria Bodard, altogether accounting for $91.2 \%$ of the whole soil seedbank throughout the two seasons. However, the ANOVA computed on RAI data of major weeds highlighted no significant effects either for cover cropping or for sampling time (data not shown).

Abundance was also analyzed by calculating the seedbank size (Table 4). The interactive effect "cover cropping $\times$ sampling time" two-way ANOVA was significant in season II $(P \leq 0.001)$ and season IV $(P \leq 0.05)$, with both factors showing significance at $P \leq 0.001$. Concerning the effect of cover cropping, the lowest seedbank size was detected in TCC-B plots (1469 seeds $\mathrm{m}^{-2}$ on the average of seasons), with a reduction of $55.4 \%$ in season II and $57.4 \%$ in season IV, as compared to CM. Overall, in both seasons, the general trend in decreasing order was $\mathrm{CM}>\mathrm{SCC}-\mathrm{S}>$ SCC-B $>$ TCC-S $>$ TCC-B (Table 4). Regarding sampling time, in both seasons, the seedbank size was significantly higher in April than in September (3380 vs. 1020 seeds m ${ }^{-2}$ in season II and 2920 vs. 1655 seeds $\mathrm{m}^{-2}$ in season IV).

Significant effects were also observed in terms of seedbank diversity and evenness (Table 4). The two studied biodiversity indices were differently affected depending on the season. In season II, TCC-B evidenced the highest $\mathrm{H}$ (1.43) and $\mathbf{J}(0.89)$, indicating a high weed diversity and no dominant species. In this season, both $\mathrm{H}$ and $\mathrm{J}$ were greater in September than in April (1.53 vs. 0.93 for $\mathrm{H}$ and 0.91 vs. 0.64 for J). In season IV, the two-way interaction was significant only for $\mathrm{H}(P \leq 0.001)$; $\mathrm{CM}$ highlighted the highest $\mathrm{H}$ (1.8) and did not differ significantly from TCC-B for $\mathbf{J}$ ( 0.93 vs. 0.87 , respectively). The lowest $\mathrm{H}$ and $\mathrm{J}$ were found in SCC-S (1.04 and 0.56) and SCC-B (1.33 and 0.7) plots. Contrariwise to season II, $\mathrm{H}$ was higher in April than in September (1.54 vs. 1.42), whereas the sampling time was not consistent for $\mathrm{J}$. 


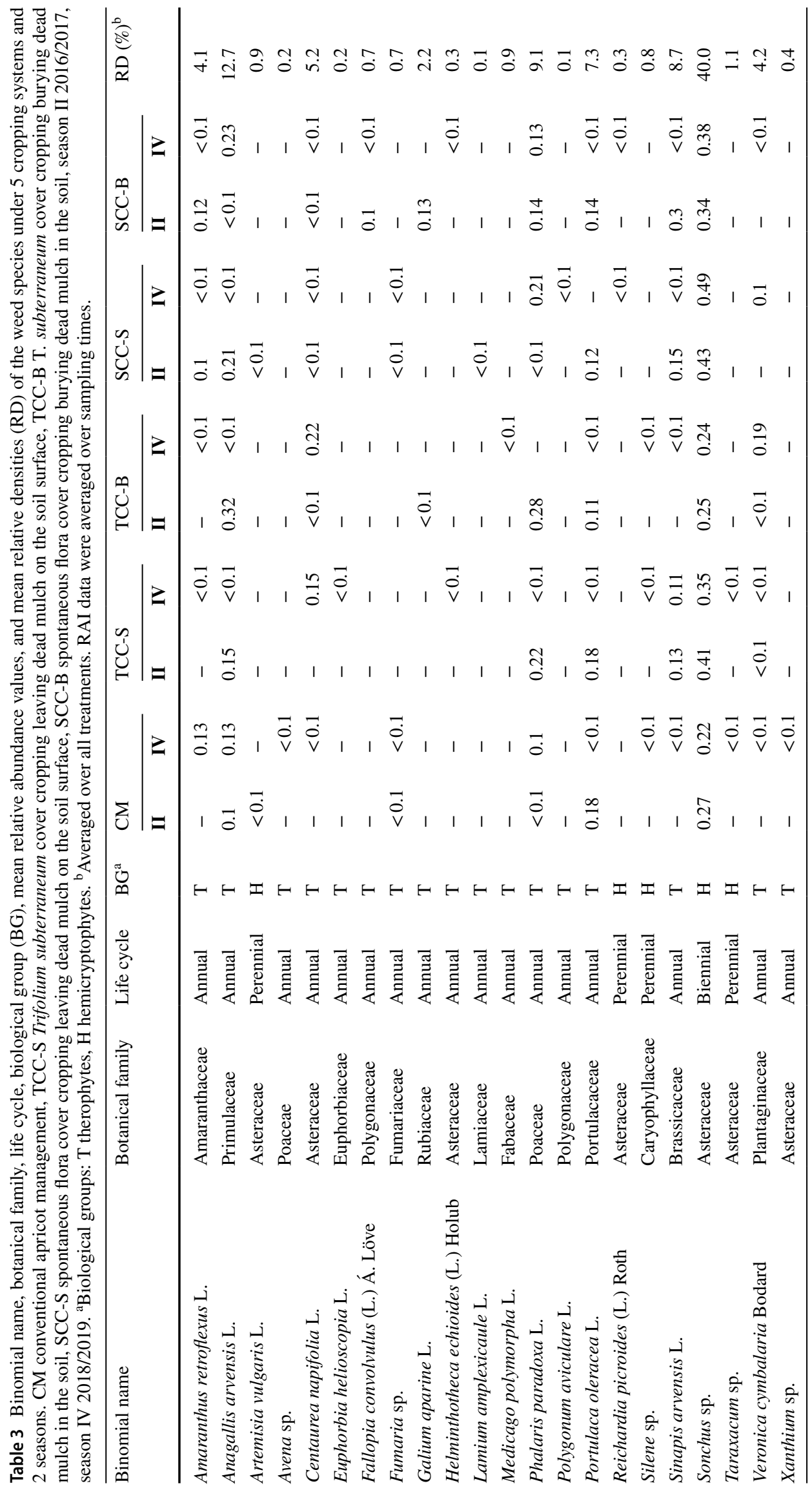


Table 4 Effect of cover cropping (CC) and soil sampling time (ST) on the weed seedbank size, Shannon diversity index $(\mathrm{H})$, and Pielou's evenness index (J) with analysis of variance (ANOVA, $P$ values). Values are means $(n=4)$ with standard deviation (in brackets). Values within a column followed by the same letters are not significantly different at $P \leq 0.05$ (LSD test). CM conventional apricot management,
TCC-S Trifolium subterraneum cover cropping leaving dead mulch on the soil surface, TCC-B T. subterraneum cover cropping burying dead mulch in the soil, SCC-S spontaneous flora cover cropping leaving dead mulch on the soil surface, SCC-B spontaneous flora cover cropping burying dead mulch in the soil, season II 2016/2017, season IV 2018/2019.

\begin{tabular}{|c|c|c|c|c|c|c|c|}
\hline \multirow[t]{2}{*}{ Treatment } & & \multicolumn{2}{|c|}{ Seedbank size (seeds $\mathrm{m}^{-2}$ ) } & \multicolumn{2}{|l|}{$\mathrm{H}$} & \multicolumn{2}{|l|}{$\mathrm{J}$} \\
\hline & & Season II & Season IV & Season II & Season IV & Season II & Season IV \\
\hline \multirow[t]{5}{*}{$\mathrm{CC}$} & $\mathrm{CM}$ & $3250(256) a$ & $3488(307) a$ & $1.10(0.37) \mathrm{b}$ & $1.80(0.06) \mathrm{a}$ & $0.80(0.06) \mathrm{ab}$ & $0.87(0.03) \mathrm{ab}$ \\
\hline & TCC-S & $1750(202) \mathrm{c}$ & $1788(380) \mathrm{cd}$ & $1.12(0.46) \mathrm{b}$ & $1.56(0.42) \mathrm{b}$ & $0.69(0.28) \mathrm{ab}$ & $0.77(0.10) b c$ \\
\hline & TCC-B & $1450(281) \mathrm{d}$ & $1488(409) \mathrm{d}$ & $1.43(0.05) \mathrm{a}$ & $1.66(0.21) \mathrm{b}$ & $0.89(0.03) \mathrm{a}$ & $0.93(0.01) \mathrm{a}$ \\
\hline & SCC-S & $2325(203) b$ & $2425(329) \mathrm{b}$ & $1.13(0.71) b$ & $1.04(0.32) \mathrm{d}$ & $0.63(0.40) \mathrm{b}$ & $0.56(0.07) \mathrm{c}$ \\
\hline & SCC-B & $2225(164) b$ & 2250 (349)bc & $1.37(0.54) \mathrm{a}$ & $1.33(0.58) \mathrm{c}$ & $0.84(0.19) \mathrm{ab}$ & $0.70(0.27) b c$ \\
\hline \multirow[t]{2}{*}{ ST } & April & $3380(358) \mathrm{a}$ & 2920 (364)a & $0.93(0.29) \mathrm{b}$ & $1.54(0.43) \mathrm{a}$ & $0.64(0.21) b$ & $0.75(0.18) \mathrm{a}$ \\
\hline & September & $1020(85) b$ & $1655(346) \mathrm{b}$ & $1.53(0.16) \mathrm{a}$ & $1.42(0.39) \mathrm{b}$ & $0.91(0.05) \mathrm{a}$ & $0.78(0.18) \mathrm{a}$ \\
\hline \multirow[t]{3}{*}{ ANOVA } & $\mathrm{CC}$ & $<0.001$ & $<0.001$ & $<0.001$ & $<0.001$ & 0.1156 & 0.0054 \\
\hline & ST & $<0.001$ & $<0.001$ & $<0.001$ & 0.0062 & $<0.001$ & 0.7875 \\
\hline & $\mathrm{CC} \times \mathrm{ST}$ & $<0.001$ & 0.0131 & $<0.001$ & $<0.001$ & 0.0949 & 0.0759 \\
\hline
\end{tabular}

MANOVA indicated a strong significance of the two-way interaction $(P \leq 0.001)$ in seasons II and IV on the composition of the weed seedbank, with sampling time contributing more to variance than cover cropping in both seasons ( $F=3360$ vs. 439.5 in season II and 6.6 vs. 3.7 in season IV). Such differences in the weed communities of the soil seedbank were represented by two ordination biplots, one per season, derived from PCA on major weeds (Fig. 5). In season II, most weeds and treatments were discriminated along the PC1 (42.4\% of variance). In particular, the weeds $A$. retroflexus and S. arvensis, together with the treatments SCC-S, SCC-B, and $\mathrm{CM}$ at the first sampling time (T1), were negatively correlated with PC1 (left side of the biplot), while all the other weeds and treatments were discriminated on the right side. CM-T1 was associated with $S$. arvensis, SCC-B-T1 and SCC-S-T1 showed no association with any weeds, and in T2, all treatments showed a lower seedbank size, except for TCC-B-T2 and CM-T2. In season IV, the discriminations were clearer. As observed in season II, the treatments at the second sampling time (T2) showed a lower seedbank, as evidenced by the fact that TCC-B-T2, TCC-S-T2, and CM-T2 were not infested by any weeds. SCC-S-T1 was highly infested with $C$. napifolia; TCC-B-T1 with Sonchus sp.; TCC-S-T1 with P. oleracea; and the spontaneous flora cover cropping (SCC-B-T2, SCC-B-T1 and SCC-S-T2) with S. arvensis, P. paradoxa and A. arvensis. All the weeds, except for $C$. napifolia and V. cymbalaria, were discriminated by the PC2 along the negative side of the axe.

\section{Discussion}

The results obtained in this 4-year field research indicate that cover cropping had remarkable effects in enhancing the levels of SOM and soil macro- and microelements as well as in reducing the number of weed seeds in the soil, as compared to the conventional management. Such results were strongly influenced by cover crop type and season, together with the sampling depth for the soil variables and sampling time for the weed seedbank.

\subsection{Soil organic matter and soil macro- and micro-elements}

The role of cover cropping on soil physical and chemical properties has been investigated (Adeli et al. 2020; Mauro et al. 2015; Nascente and Stone 2018; Ramos et al. 2020; Wulanningtyas et al. 2021). In the present study, the best results were obtained by adopting $T$. subterraneum with dead mulches incorporated into the soil (TCC-B). The intensity of these increases was much higher in season IV than II, likely due to a cumulative effect, although subterranean clover biomass showed an opposite trend $\left(283 \mathrm{~g} \mathrm{DW} \mathrm{m}^{-2}\right.$ in season II and $159 \mathrm{~g} \mathrm{DW} \mathrm{m}^{-2}$ in season IV). Therefore, in contrast with the work of Roldán et al. (2003), reporting higher values in the soil physio-chemical properties on increasing the amount of residue cover, here no relationship was detected between soil variables and cover crop biomass. Moreover, higher amounts of SOM and soil chemical variables were generally found in the $0-20-\mathrm{cm}$ layer than in the deeper one, as commonly indicated in literature (Wang et al. 2008). Our results were corroborated by Wulanningtyas et al. (2021), who reported that the combination of no tillage and rye (Secale cereale L.) cover crop was very effective in increasing the levels of soil organic carbon, total $\mathrm{N}$, available $\mathrm{P}$, exchangeable bases ( $\mathrm{K}, \mathrm{Ca}, \mathrm{Mg}, \mathrm{Na}$ ), cation exchange capacity, and some soil physical and biological properties, mainly in the 25 - 75-cm layer. Similarly, Adeli et al. (2020) indicated that the integration of winter cover crops and soil amendments 

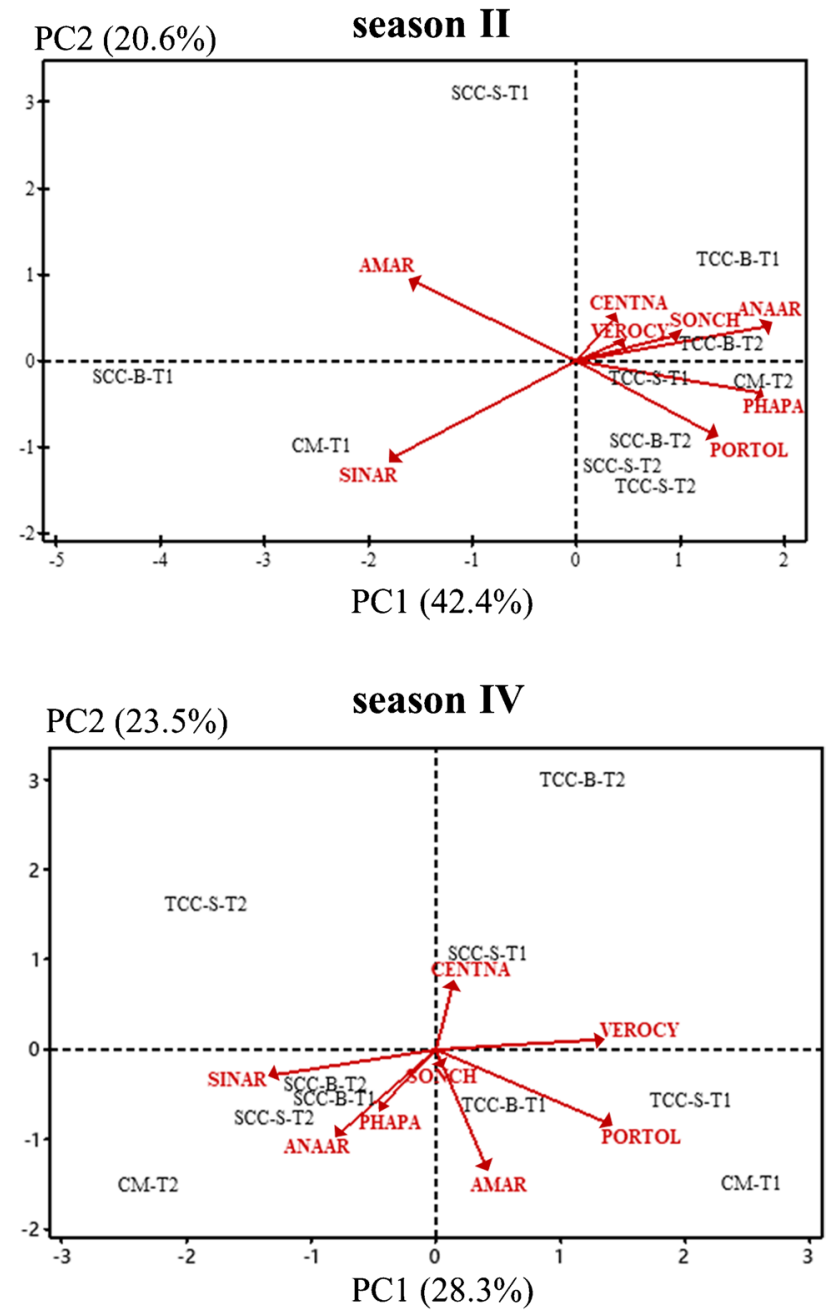

Fig. 5 Principal components analysis ordination biplot with the 8 most abundant weed species and genera. Red names and arrows highlight the discrimination of weeds along the principal components. Season II, 2016/2017; season IV, 2018/2019; $\mathrm{T}_{1}$, April; $\mathrm{T}_{2}$, September; TCC-S, Trifolium subterraneum cover cropping leaving dead mulch on the soil surface; TCC-B, T. subterraneum cover cropping burying dead mulch in the soil; SCC-S, spontaneous flora cover cropping leaving dead mulch on the soil surface; SCC-B, spontaneous flora cover cropping burying dead mulch in the soil; $\mathrm{CM}$, conventional apricot management. AMAR, Amaranthus retroflexus; ANAAR, Anagallis arvensis; CENTNA, Centaurea napifolia; PHAPA, Phalaris paradoxa; PORTOL, Portulaca oleracea; SINAR, Sinapis arvensis; SONCH, Sonchus sp.; VEROCY, Veronica cymbalaria.

into no-till cropping systems improved the soil total carbon and several soil physical, hydrological, and microbial properties. Ramos et al. (2020) also found that oat-vetch cover crops enhanced soil quality (SOM and total $\mathrm{N}$ content, phosphatase, and $\beta$-glucosidase activities) in semiarid environments compared to frequently tilled management. Here, the significant improvement of SOM in TCC-B plots was probably caused by a multiple cascading effect of carbon input from residue decomposition, carbon capture from the atmosphere via photosynthesis of the cover crop (MoebiusClune et al. 2016), and direct root exudation of C-containing compounds into the rhizosphere (Scavo et al. 2019b). In this regard, Marschner (1995) estimated that about 5-21\% of all photosynthetically fixed carbon is released into the rhizosphere through root exudation. The increase in SOM on one side and the release of rhizodeposits (e.g., $\mathrm{Ca}^{2+}$, $\mathrm{Fe}^{2+}$ and $\mathrm{Fe}^{3+}, \mathrm{Al}^{3+}, \mathrm{K}^{+}$, as well as mucilages and several organic compounds) from the cover crop on the other contribute to promote the formation of aggregates and, thus, to improve the soil structure, the cation exchange capacity, and the microbial activity (Scavo et al. 2019b). The stimulation of the soil enzymatic-complex activity and promotion of the soil microbial biomass are often reported in cover cropping field experiments (Adeli et al. 2020; Nunes et al. 2018). The incorporation of plant residues into the soil, in particular, increases soil $\mathrm{N}$ richness, soil temperature, and aeration, thus creating favorable conditions for microorganisms (Turmel et al. 2015), including plant-promoting bacteria and arbuscular mycorrhizal fungi, which are of key importance in enhancing soil $\mathrm{P}$ availability and biological fixation. Overall, these effects may explain the increase in soil macro- and microelement levels. Furthermore, buried plant residues show a faster decomposition and mineralization rate than surface ones.

In our previous research, TCC-B ensured a major increase in the amount of Nitrosomonas europaea and Azotobacter vinelandii, two of the most important bacteria involved in the soil N-cycle, in addition to an enhancement of the soil mineral $\mathrm{N}$ (Scavo et al. 2020). After another year of cover cropping, the $\mathrm{NH}_{4}{ }^{+}$and the total mineral $\mathrm{N}$ content were further increased respectively by $56 \%$ and $14 \%$ in March and by $34 \%$ and $12 \%$ in June, compared to season III. The increases in mineral $\mathrm{N}$ were more marked than those detected for the total $\mathrm{N}$, since the latter is largely composed of organic $\mathrm{N}$, which is unavailable for plants and therefore of less importance for plant nutrition. The higher amounts of soil mineral $\mathrm{N}$ in the June sampling can be attributed to weather conditions, since the higher temperature and the lower soil moisture of late spring are favorable for $\mathrm{N}$ mineralization. Given the low number of Fabaceae members detected in the soil weed seedbank, it is reasonable to assume that the higher amount of $\mathrm{N}$ released into the soil in TCC-B and TCC-S than the other treatments was caused by the massively inclusion of a $\mathrm{N}$-fixing species like $T$. subterraneum. The higher soil $\mathrm{N}$-content caused by $T$. subterraneum than spontaneous flora cover cropping is in accordance with Kuo and Jellum (2002), who indicated that as plant tissue $\mathrm{N}$ increased and tissue $\mathrm{C} / \mathrm{N}$ ratio decreased (typical characteristics of leguminous species), the $\mathrm{N}$ mineralization rate increased. Similarly to SOM and macro- and microelements, TCC-B performed better than TCC-S in enhancing the mineral $\mathrm{N}$ content, likely due to the faster decomposition rate of subterranean clover 
residues into the soil. The work of Kuo and Jellum (2002) also states that the incorporation of cover crop residues shows higher soil organic $\mathrm{C}$ and $\mathrm{NO}_{3}{ }^{-}$than removing them. In a recent study, Lombardo et al. (2021) found that TCC-B improved the nutritional status of the apricot by significantly increasing the content of macro- and micronutrients in both leaves and fruits than spontaneous flora and CM, thus demonstrating how the beneficial effects on soil properties were reflected in the plants.

\subsection{Weed soil seedbank}

The effects of 4 years cover cropping on weed management were evaluated on the soil seedbank at a depth of $10-15 \mathrm{~cm}$, where most weed seeds are commonly concentrated (Swanton et al. 2000). In accordance with Scavo et al. (2020), a total of 22 taxa was detected, mainly belonging to the Asteraceae family, the most diffused weed botanical family in Mediterranean agroecosystems (Restuccia et al. 2019). Weed communities were dominated by therophytes and annual spring-summer weeds such as Sonchus sp., A. retroflexus, $P$. oleracea, $P$. paradoxa, C. napifolia, $S$. arvensis, and $V$. cymbalaria, which showed an RD $>4 \%$. However, in agreement with our previous study (Scavo et al. 2020) and other researches (Swanton et al. 1999), cover cropping and sampling time did not have significant effects on RAI data, as no consistent effects were either observed on species richness. The lack of substantial changes in the number of weed species among cover cropping treatments is a wide phenomenon (Ngouajio et al. 2003; Swanton et al. 1999) that some authors attribute to the "buffering" effect of the weed seedbank, basically caused by weed seed longevity (Bàrberi and Lo Cascio 2001). On the contrary, such effects are often evident on the emerged weed flora, as found in our previous research (Restuccia et al. 2020) where TCC-S reduced by $21 \%$ species richness compared to $\mathrm{CM}$. Concerning the seedbank size, TCC-B proved to be the most efficient treatment in reducing the number of weed seeds in the soil, even after another growing season with respect to our previous research, with a mean reduction of $-57.4 \%$ compared to $\mathrm{CM}$, followed by spontaneous flora cover cropping. The phytotoxic effect of subterranean clover was stronger in April than September, also due to the higher seedbank size in spring. It is likely that the differences in the seedbank size between April and September are due to (i) the high presence of annual spring-summer weeds with high dormancy rate during autumn, (ii) seed germination of annual weeds promoted by late summer-early autumn rainfall, and (iii) species whose seeds massively germinate with autumn rainfall are hard to detect in spring (Buisson et al. 2018). Anyway, a higher seedbank size in spring than autumn is a common situation in Mediterranean environments. Probably, the severe drought conditions typical of the late spring and summer associated with the lack of available food resources from grain crops, which are normally harvested in the same period, may have promoted the predation of weed seeds by birds and edaphic fauna. Under rainfed conditions and low-input agricultural regime such as that of our experiment, several studies have found significant weed seed loss from predation when seeds remained on the soil surface, up to $60-70 \%$ (Buhler et al. 1997). In addition, in the late spring and summer, the level of subterranean clover allelochemicals accumulated into the rhizosphere ( $15 \mathrm{~cm})$ reach the climax due to a cumulative effect and to the low rainfall which limits their leaching, thus increasing the fatal seed germination. Moreover, the soil seedbank here detected was primarily composed by annual spring-summer therophytes needing a cold period over winter to broke seed dormancy. For such weeds, the dormancy is broken in late spring so that their seeds are less detected in autumn (Buhler et al. 1997). Interestingly, the long-term effect of cover cropping was not limited only to weeds with the same germination seasonality (i.e., autumn/winter germinating species), but subterranean clover had an effect independently from its phase. A similar result was found by Bàrberi and Mazzoncini (2001). Furthermore, in their work, the authors reported a not-significant reduction of the seedbank density by using subterranean clover in a conventional tillage system while becoming relevant $(-22 \%)$ if combined with no tillage. It is known that cover crops can be differently managed within the orchards by moving or incorporating the plant biomass in order to mitigate their competition with trees. A study conducted in an apricot orchard in Turkey using Vicia villosa Roth, V. pannonica, V. pannonica + Triticale $(70+30 \%)$, Phacelia tanacetifolia Benth. and Fagopyrum esculentum Moench cover cropping evidenced that these species effectively reduced weed richness and density (Tursum et al. 2018). In addition, the management of these cover crops through the residue incorporation into the soil enhanced the weed suppression compared to herbicidal (glyphosate) or mechanical control (Tursun et al. 2018). The effects obtained here on the soil seedbank were reflected also on the real weed flora, given that $T$. subterraneum significantly decreased the aboveground weed biomass up to $86 \%$, with a positive correlation between weed growth suppression and cover crop biomass (Restuccia et al. 2020). The higher phytotoxicity of subterranean clover cover cropping than spontaneous flora is explained by physio-chemical processes. The physical interference is caused by its strong competitive capacity for water, nutrients, light, and space, while the secondary metabolites (essentially phenolic compounds and polyphenols) released into the soil via root exudation and decomposition from plant residues-especially when incorporated into the soil (TCCB) — are involved in the chemical interference.

The eventual presence of associations between treatments under study and weeds was analyzed by PCA on those species showing a high enough density (i.e., major weeds). 
Most variation in the species composition was explained by sampling time, considering that several treatments showed no weed infestation in the autumn sampling, whereas during spring, the treatments were highly infested. As observed for the emerged weed flora (Restuccia et al. 2020), TCC-B-T2 did not show any particular association with weeds, and its soil seedbank evenness was very high (0.93), indicating the absence of dominant species. The lowest biodiversity was found in the spontaneous flora cover cropping treatments, which at the same time also showed the lowest evenness, thus confirming the association emerging from the multivariate analysis. Overall, cover cropping did not determine relevant shifts in weed populations. Other studies have shown no clear patterns in weed communities during cover cropping experiments (Moonen and Bàrberi 2004; Shrestha et al. 2002; Swanton et al. 1999). Indeed, cover crop type, management practices, and several biotic and abiotic factors closely influence both species composition and weed patterns in the soil seedbank. Moreover, it is necessary to keep in mind also that the measured soil seedbank does not necessarily represent the weed species able to germinate and growth

\section{Conclusions}

This study highlights the benefits deriving from the use of subterranean clover cover cropping, especially when incorporating its dead mulches into the soil, in Mediterranean orchards. The cumulative $T$. subterraneum cover cropping for four consecutive years led to a significant improvement in SOM, macro- and microelement levels, a decrease in weed pressure, and an enhancement in weed biodiversity, which have also resulted in positive effects on the productive performance of the apricot orchard. These principles can be applied to similar agroecosystems with a Mediterranean climate as sustainable agronomic practice for enhancing soil fertility while reducing the need for intensive tillage, mineral fertilizers, and synthetic herbicides.

Acknowledgements The authors thank Mr. Angelo Litrico for his excellent agronomic assistance during field trials. We gratefully acknowledge also the FONTANAZZA farm (Caltanissetta, Italy) for hosting the field experiment.

Authors' contributions Conceptualization: G.M. Methodology: A.S., A.R., S.L., C.A., G.P., S.F., U.A., and G.M. Investigation and Data Curation: A.S, A.R., S.L., S.F., C.A., G.P., and U.A. Writing, Original Draft: A.S. and U.A. Writing, Rewiew and Editing: A.S., A.R., C.A., and U.A. Supervision: G.M.

Funding Open access funding provided by Università degli Studi di Catania within the CRUI-CARE Agreement.
Data availability The datasets analyzed during the current study are available from the corresponding author on reasonable request.

\section{Declarations}

Ethics approval Not applicable

Consent to participate Not applicable.

Consent for publication Not applicable.

Conflict of interest The authors declare no competing interests.

Open Access This article is licensed under a Creative Commons Attribution 4.0 International License, which permits use, sharing, adaptation, distribution and reproduction in any medium or format, as long as you give appropriate credit to the original author(s) and the source, provide a link to the Creative Commons licence, and indicate if changes were made. The images or other third party material in this article are included in the article's Creative Commons licence, unless indicated otherwise in a credit line to the material. If material is not included in the article's Creative Commons licence and your intended use is not permitted by statutory regulation or exceeds the permitted use, you will need to obtain permission directly from the copyright holder. To view a copy of this licence, visit http://creativecommons.org/licenses/by/4.0/.

\section{References}

Adeli A, Brooks JP, Read JJ, Feng G, Miles D, Shankle MW, Barksdale N, Jenkins JN (2020) Management strategies on an upland soil for improving soil properties. Commun Soil Sci Plan 51:413-429. https://doi.org/10.1080/00103624.2019.1709490

Adeux G, Vieren E, Carlesi S, Bàrberi P, Munier-Jolain N, Cordeau S (2019) Mitigating crop yield losses through weed diversity. Nat Sustain 2:1018-1026. https://doi.org/10.1038/ s41893-019-0415-y

Bàrberi P, Mazzoncini M (2001) Changes in weed community composition as influenced by cover crop and management system in continuous corn. Weed Science 49(4):491-499. https://doi.org/ 10.1614/0043-1745

Bárberi P, Lo Cascio B (2001) Long-term tillage and crop rotation effects on weed seedbank size and composition. Weed Res 41:325-340. https://doi.org/10.1046/j.1365-3180.2001.00241.x

Blanco-Canqui HB, Shaver TM, Lindquist JL, Shapiro CA, Elmore RW, Francis CA, Hergert GW (2015) Cover crops and ecosystem services: insights from studies in temperate soils. Agron J 107:2449-2474. https://doi.org/10.2134/agronj15.0086

Buhler DD, Hartzler RG, Forcella F (1997) Weed seed bank dynamics: implications to weed management. J Crop Prod 1:145-168. https://doi.org/10.1300/J144v01n01_07

Buisson E, Jaunatre R, Römermann C, Bulot A, Dutoit T (2018) Species transfer via topsoil translocation: lessons from two large Mediterranean restoration projects. Restor Ecol 26(S2):S179-S188. https://doi.org/10.1111/rec.12682

Conti F, Abbate G, Alessandrini A, Blasi C (2005) An annotated checklist of the Italian vascular flora. Palombi Ed., Rome.

Crooke WM, Simpson WE (1971) Determination of ammonium in Kjeldahl digests of crops by an automated procedure. J Sci Food Agr 22:9-10. https://doi.org/10.1002/jsfa.274022010

Daryanto S, Jacinthe PA, Fu BJ, Zhao WW, Wang LX (2019) Valuing the ecosystem services of cover crops: barriers and pathways 
forward. Agr Ecosyst Environ 270:76-78. https://doi.org/10. 1016/j.agee.2018.10.021

Enache AJ, Ilnicki RD (1990) Weed control by subterranean clover (Trifolium subterraneum) used as a living mulch. Weed Technol 4(3):534-538. https://doi.org/10.1017/S0890037X0 0025926

European Commission (EC) (2019) Communication from the Commission. The European Green Deal. https://ec.europa.eu/info/strat egy/priorities-2019-2024/european-green-deal_en Accessed 11 November 2020.

Finney DM, Kaye JP (2017) Functional diversity in cover crop polycultures increases multifunctionality of an agricultural system. J Appl Ecol 54:509-517. https://doi.org/10.1111/1365-2664.12765

Gomez KA, Gomez AA (1984) Statistical procedures for agricultural research. John Wiley \& Sons, New York

Jiménez MP, de la Horra AM, Pruzzo L, Palma RM (2002) Soil quality: a new index based on microbiological and biochemical parameters. Biol Fert Soils 35:302-306. https://doi.org/10.1007/ s00374-002-0450-z

Kaye JP, Quemada M (2017) Using cover crops to mitigate and adapt to climate change. A Review Agron Sustain Dev 37:4. https://doi. org/10.1007/s13593-016-0410-x

Kuo S, Jellum EJ (2002) Influence of winter cover crop and residue management on soil nitrogen availability and corn. Agron J 94:501-508. https://doi.org/10.2134/agronj2002.5010

Legendre P, Legendre L (2012) Numerical ecology. Elsevier, Amsterdam, The Netherlands

Lindsay WL, Norwell WA (1978) Development of DTPA soil test for zinc, iron, manganese and copper. Soil Sci Soc Am J 42:421-428. https://doi.org/10.2136/sssaj1978.0361599500 4200030009x

Lombardo S, Pandino G, Mauromicale G (2014) The mineral profile in organically and conventionally grown early crop potato tubers. Sci Hortic-Amsterdam 167:169-173. https://doi.org/10. 1016/j.scienta.2014.01.006

Lombardo S, Restuccia A, Abbate C et al (2021) Trifolium subterraneum cover cropping for improving the nutritional status of a Mediterranean apricot orchard. J Sci Food Agr 101:3767-3777. https://doi.org/10.1002/jsfa.11009

Madejón E, Moreno F, Murillo JM (2007) Soil biochemical response to long-term conservation tillage under semi-arid Mediterranean conditions. Soil till Res 94:346-352. https://doi.org/10.1016/j. still.2006.08.010

Marschner H (1995) Mineral nutrition of higher plants. Academic Press, London, UK

Mauro RP, Anastasi U, Lombardo S, Pandino G, Pesce GR, Restuccia A, Mauromicale G (2015) Cover crops for managing weeds soil chemical fertility and nutritional status of organically grown orange orchard in Sicily. Ital J Agron 10(2):101-104. https://doi.org/10.4081/ija.2015.641

Mauro RP, Occhipinti A, Longo AMG, Mauromicale G (2011) Effects of shading on chlorophyll content, chlorophyll fluorescence and photosynthesis of subterranean clover. J Agron Crop Sci 197(1):57-66. https://doi.org/10.1111/j.1439-037X.2010. 00436.x

Mauromicale G, Occhipinti A, Mauro R (2010) Selection of shadeadapted subterranean clover species for cover cropping in orchards. Agron Sustain Dev 30(2):473-480. https://doi.org/ 10.1051/agro/20090

Moebius-Clune BN, Moebius-Clune D, Gugino B, Idowu OJ, Schindelbeck RR, Ristow AJ, van Es H, Thies J, Shayler H, McBride M, Wolfe D, Abawi G (2016). Comprehensive Assessment of Soil Health - the Cornell Framework Manual. https://doi.org/ 10.1080/00461520.2015.1125787

Moonen AC, Bàrberi P (2004) Size and composition of the weed seedbank after 7 years of different cover crop- maize management systems. Weed Res 44(3):163-177. https://doi. org/10.1111/j.1365-3180.2004.00388.x

Moreno B, García-Rodríguez S, Cañizares R, Castro J, Benítez E (2009) Rainfed olive farming in south-eastern Spain: longterm effect of soil management on biological indicators on soil quality. Agr Ecosyst Environ 131:333-339. https://doi.org/10. 1016/j.agee.2009.02.011

Nascente AS, Stone LF (2018) Cover crops as affecting soil chemical and physical properties and development of upland rice and soybean cultivated in rotation. Rice Sci 25:340-349. https://doi. org/10.1016/j.rsci.2018.10.004

Ngouajio M, McGiffen ME Jr, Hutchinson CM (2003) Effect of cover crop and management system on weed populations in lettuce. Crop Prot 22(1):57-64. https://doi.org/10.1016/S0261-2194(02) 00111-4

Nkoa R, Owen MDK, Swanton CJ (2015) Weed abundance, distribution, diversity, and community analyses. Weed Sci 63:64-90. https://doi.org/10.1614/WS-D-13-00075.1

Nunes MR, van Es HM, Schindelbeck R, Ristow AJ, Ryan M (2018) No-till and cropping system diversification improve soil health and crop yield. Geoderma 328:30-43. https://doi.org/10.1016/j. geoderma.2018.04.031

Ramos ME, Benítez E, García PA, Robles AB (2020) Cover crops under different managements vs. frequent tillage in almond orchards in semiarid conditions: effects on soil quality. Appl Soil Ecol 44:6-14. https://doi.org/10.1016/j.apsoil.2009.08.005

Restuccia A, Lombardo S, Mauromicale G (2019) Impact of a cultivation system upon the weed seedbank size and composition in a Mediterranean environment. Agriculture 9(9):192. https:// doi.org/10.3390/agriculture9090192

Restuccia A, Scavo A, Lombardo S, Pandino G, Fontanazza S, Anastasi U, Abbate C, Mauromicale G (2020) Long-term effect of cover crops on species abundance and diversity of weed flora. Plants 9(11):1506. https://doi.org/10.3390/plants9111506

Roldán A, Caravaca F, Hernández MT, Garcıa C, Sánchez-Brito C, Velásquez M, Tiscareño M (2003) No-tillage, crop residue additions, and legume cover cropping effects on soil quality characteristics under maize in Patzcuaro watershed (Mexico). Soil till Res 72:65-73. https://doi.org/10.1016/S0167-1987(03)00051-5

Scavo A, Abbate C, Mauromicale G (2019b) Plant allelochemicals: agronomic, nutritional and ecological relevance in the soil system. Plant Soil 442:23-48. https://doi.org/10.1007/ s11104-019-04190-y

Scavo A, Mauromicale G (2020) Integrated weed management in herbaceous field crops. Agronomy 10(4):466. https://doi.org/ 10.3390/agronomy 10040466

Scavo A, Restuccia A, Abbate C, Mauromicale G (2019a) Seeming field allelopathic activity of Cynara cardunculus L. reduces the soil weed seed bank. Agron Sustain Dev 39:41. https://doi.org/ 10.1007/s13593-019-0580-4

Scavo A, Restuccia A, Lombardo S, Fontanazza S, Abbate C, Pandino G, Anastasi U, Onofri A, Mauromicale G (2020) Improving soil health, weed management and nitrogen dynamics by Trifolium subterraneum cover cropping. Agron Sustain Dev 40:18. https://doi.org/10.1007/s13593-020-00621-8

Sharma P, Singh A, Kahlon CS, Brar AS, Grover KK, Dia M, Steiner RL (2018) The role of cover crops towards sustainable soil health and agriculture - a review paper. Am J Plant Sci 9:19351951. https://doi.org/10.4236/ajps.2018.99140

Sharma V, Irmak S, Padhi J (2018) Effects of cover crops on soil quality: part I. Soil chemical properties - organic carbon, total nitrogen, $\mathrm{pH}$, electrical conductivity, organic matter content, nitrate-nitrogen, and phosphorus. J Soil Water Conserv 73:637651. https://doi.org/10.2489/jswc.73.6.637

Shrestha A, Knezevic SZ, Roy RC, Ball-Coelho BR, Swanton CJ (2002) Effect of tillage, cover crop and crop rotation on the 
composition of weed flora in a sandy soil. Weed Res 42:76-87. https://doi.org/10.1046/j.1365-3180.2002.00264.x

Soil Survey Staff (1999) Soil taxonomy: A basic system of soil classification for making and interpreting soil surveys (2nd ed.). Agricultural Handbook 436, Natural Resources Conservation Service, USDA, Washington DC, USA, pp. 869.

Swanton CJ, Shrestha A, Knezevic SZ, Roy RC, Ball-Coelho BR (2000) Influence of tillage type on vertical weed seedbank distribution in a sandy soil. Can J Plant Sci 80:455-457. https:// doi.org/10.4141/P99-020

Swanton CJ, Shrestha A, Roy RC, Ball-Coelho BR, Knezevic SZ (1999) Effect of tillage systems, N, and cover crop on the composition of weed flora. Weed Sci 47(4):454-461. https://doi.org/ 10.1017/S0043174500092079

Travlos IS, Cheimona N, Roussis I, Bilalis DJ (2018) Weed-species abundance and diversity indices in relation to tillage systems and fertilization. Front Environ Sci 6:11. https://doi.org/10. 3389/fenvs.2018.00011

Turmel MS, Speratti A, Baudron F, Verhulst N, Govaerts B (2015) Crop residue management and soil health: a systems analysis. Agr Syst 134:6-16. https://doi.org/10.1016/j.agsy.2014.05.009
Tursun N, Işık D, Demir Z, Jabran K (2018) Use of living, mowed, and soil incorporated cover crops for weed control in apricot orchards. Agronomy 8(8):150. https://doi.org/10.3390/agron omy 8080150

United Nation (UN) (2015) Transforming our world: the 2030 Agenda for Sustainable Development. United Nations, New York. https:// www.un.org/sustainabledevelopment/development-agenda/ Accessed 10 November 2020.

Wang Q, Bai Y, Gao H, He J, Chen H, Chesney RC, Kuhn NJ, Li H (2008) Soil chemical properties and microbial biomass after 16 years of no-tillage farming on the Loess Plateau, China. Geoderma 144:502-508. https://doi.org/10.1016/j.geoderma.2008. 01.003

Wulanningtyas HS, Gong Y, Li P, Sakagami N, Nishiwaki J, Komatsuzaki M (2021) A cover crop and no-tillage system for enhancing soil health by increasing soil organic matter in soybean cultivation. Soil till Res 205:104749. https://doi.org/10.1016/j.still.2020. 104749

Publisher's note Springer Nature remains neutral with regard to jurisdictional claims in published maps and institutional affiliations. 